\title{
ERMITAS, CONVENTOS Y COFRADÍAS EN TIERRAS DE ALICANTE DURANTE LA EDAD MEDIA
}

\author{
José Hinojosa Montalvo \\ Universidad de Alicante
}

Durante la Edad Media las tierras alicantinas estuvieron eclesiásticamente divididas, adscritas a dos diócesis diferentes, la de Valencia y la de Cartagena (luego Murcia), como consecuencia de la pertenencia durante el siglo XIII de las comarcas meridionales, las situadas al sur de la línea Biar-Jijona-Villajoyosa, a la Corona de Castilla (1). Tras la anexión e incorporación de estas tierras al reino de Valencia (1296-1305) siguieron perteneciendo a la provincia eclesiástica castellana, a pesar de los esfuerzos de Orihuela por conseguir una diócesis propia, lo que no se logró hasta el siglo XVI, en 1564 (2).

La conquista del territorio llevó pareja su organización eclesiástica, el encuadramiento de los individuos, mediante la creación de una red de parroquias, que se perfilan como el instrumento religioso por excelencia, sobre todo en esta tierra de frontera, con una densidad de población mudéjar muy elevada, tal como ha estudiado R.I. Burns para el siglo XIII (3).

Sin embargo, a pesar de que cada vez se enriquece más la bibliografía sobre el Medievo alicantino, carecemos de una visión global de lo que fue la Iglesia en estos siglos en las comarcas meridionales del reino de $\mathrm{Va}$ lencia, el papel desempeñado en la sociedad, cuáles fueron las manifestaciones religiosas, cómo vivió el individuo la religión, de la difusión del dogna y la liturgia, de las supersticiones y milagros, etc. Hay algunas noticias 
dispersas en monografías locales, a las que nos referiremos, pero pocos estudios concretos (4). En este trabajo no pretendemos ofrecer una visión exhaustiva de la religiosidad de los alicantinos de la época, sino aproximarnos a las bases materiales y humanas en cuyo seno y entorno se fragua dicha religiosidad, a través de tres entes hasta ahora poco estudiados en el Alicante medieval, como son las ermitas, los conventos y las cofradías, desde el ascetismo solitario a la fraternidad colectiva.

\section{LAS ERMITAS.}

El ermitaño es un personaje del que tenemos pocas noticias para este periodo en tierras alicantinas. Suele ser una persona conocida entre el vecindario y los moradores de la localidad o comarca donde se emplaza la ermita, pero generalmente suele permanecer anónimo para el historiador y sólo en circunstancias excepcionales emerge de estas brumas del anonimato y nos deja entrever algunos aspectos de su personalidad y sus actividades.

El más célebre de estos personajes fue Pere Joan Escuder, que vivía en los años treinta y cuarenta del siglo XV en la ermita de Sant Cristòfol de Cocentaina, en las faldas de la sierra Mariola, siendo oriundo de esta villa, según algunos autores, mientras que $F$. Diago lo hace catalán. Su vida ejemplar, contemplativa, le ganaron la admiración de los vecinos. Pero lo que realmente le dió fama y renombre fueron sus profecías, hasta el punto de que en 1435, cuando se produjo la derrota naval de Ponza y la prisión de Alfonso $V$ y de sus hermanos, don Juan y don Enrique, la reina María envió un mensajero al baile general del reino, Joan Mercader, para que fuera a hablar con Pere Joan Escuder y le pidiera que encomendara a Dios al rey y sus cuñados en aquellos momentos tan penosos. Es un testimonio de lo extendida que estaba la fama de santidad de este hombre, hasta el punto de alcanzar a los círculos cortesanos. La respuesta del ermitaño para confortar a la reina fue predecir la próxima liberación del rey y de sus hermanos, a lo que seguirían faustos acontecimientos (6).

Podemos imaginar las repercusiones que el cumplimiento de lo predicho tendría en la mentalidad de aquellas gentes y el aumento de la fama del ermitaño. La mujer de Joan de Próxita, señor de Cocentaina, lo tenía en gran estima y lo veneraba como un santo. 
Según el historiador Escolano profetizó la toma de Constantinopla por los turcos y las dificultades que sufriría la Iglesia Católica; la unión de las Coronas de Aragón y Castilla; su confederación con el imperio alemán y la casa de Austria; la aparición del protestantismo; el bautismo de muchos moros, su levantamiento y expulsión de España, y la toma y recuperación de Jerusalén por los cristianos, la única profecía que, por lo que vemos, no se ha cumplido (7).

Lo cierto es que Pere Joan Escuder mantuvo correspondencia con la corte, miembros de la nobleza y de la clerecía valenciana y su fama culminó con el prodigio obrado en el momento de su muerte, acaecida el 31 de diciembre de 1444, cuando la campana de la iglesia parroquial de la villa se puso a tañer sola. Al penetrar en el templo la mujer de Joan de Próxita, que había acudido a verle por estar enfermo, lo encontró muerto, arrodillado delante del altar y Cocentaina siempre lo tuvo como uno de sus hijos predilectos, estando expuestos sus restos durante largo tiempo a la veneración pública. La noticia de su muerte la recogió el anónimo autor del "Dietari del Capellà d'Anfós el Magnànim" con estas frases:

"En l'any de M CCCC XXXXIIII, a XXXI de deembre, mori frare Johan Escuder, ermita de la ermita de Sant Cristofol de Cocentayna, lo qual dia moltes coses del esdevenydor" (8).

Otro ermitaño del que nos han llegado noticias es un tal fray B. Izquierdo, que en 1411 fue acusado por el vicario de Orihuela de herejías y sortilegios, requiriendo al gobernador general su prisión, a lo que se negó Olfo de Próxita, alegando que los vecinos no podían ser citados judicialmente fuera de la villa. El vicario se quejó al Consell y amenazó con lanzar el entredicho sobre Orihuela, pero no se consiguió que el gobernador cediera en su postura. La tensión entre el vicario y el Consell fue en aumento, aunque aquél no logró la cesión de Izquierdo. Era una muestra más de las tensiones que generaba en Orihuela su adscripción al obispado de Murcia y la defensa a ultranza de unos derechos y prerrogativas a las que cada parte se creía con derecho.

También hubo mujeres que se retiraron a la vida contemplativa, destacando por su santidad Caterina Veas, oriunda de Jávea, que se dedicó a practicar la penitencia en el cabo de San Antonio, junto a su ermita, en una cueva a cuyos pies se abría el mar, más tarde conocida como cueva de sor Basota. Era otro ejemplo de la devoción personal que se extendía a fines del Medievo por Occidente, en este caso de la religiosidad femenina. 
También en este caso la ermitaña contó con la protección de personajes notables, como el conde de Denia, don Alfonso. Gracias a su intercesión ante su hermano el cardenal obispo de Valencia, don Jaime de Aragón, concedió a Caterina el 1 de julio de 1377 facultad para que pudiera construir una ermita cerca de su celda en honor de San Antonio, confesor, levantando un altar para celebrar misa, debiendo rendir cuentas a la parroquia de Denia de las limosnas y dinero recaudado en dicha ermita. Igualmente se le dió permiso para elegir allí sepultura y nombrar su sucesora al frente de la ermita.

También el infante Marín -futuro Martín el Humano- le concedió el 21 de julio de 1387 ciertos censos que percibía de la partida llamada el Real, para que los invirtiera en la construcción de la ermita. Sor Caterina Bas todavía vivía en 1398. Su labor, tras una etapa difícil posterior a su muerte, la prosiguió otra ermitaña famosa, sor Andrea de Rostoro a mediados del sigio XV (10).

En el término de Denia, en la meseta que la separa de Jávea, prolongación del Montgó, se dan unas condiciones naturales que propician el aislamiento anacoreta, cual es la existencia de varias cuevas y de agua potable. El resultado será la instalación de numerosos ermitaños por la zona, al menos desde el siglo XIV, en que tenemos noticias documentadas de tales personajes. Cabe pensar que muchos de ellos serian gentes que se refugiaban en la vida contemplativa huyendo de las calamidades de la época, sobre todo de las epidemias que tan duramente habían castigado al reino de Valencia desde 1348, igual que al resto de Occidente, así como la guerra con Castilla, la de los dos Pedros, que en esta comarca de la Marina tuvo uno de sus más activos frentes.

Con el transcurso de los años este eremitismo evolucionó en una doble dirección: por un lado, hacia la vida cenobítica en común, con la fundación del monasterio de San Jerónimo, al que más adelante me referiré; por otro, el mantenimiento de las formas de espiritualidad aisladas, el individualismo del eremita, cuyo reflejo es la ermita del cabo de San Antonio, la más famosa de la zona debido a las virtudes cristianas que adornaron a su fundadora y alguna de sus sucesoras. A ellas me referiré también más adelante de forma más específica.

Por ahora digamos que esta ermita de San Antonio es la que más noticias nos ha dejado, y su importancia queda testimoniada en el hecho de dar nombre al promontorio donde se asentó, el cabo de San Antonio. A él se refirió con bastante detalle Roque Chabás en su "Historia de Denia" 
(11) al hablar de Caterina Bas. El lugar debía contar con una ancestral dedicación eremítica, pues el hoy conocido como cabo de San Antonio era conocido como Cap de la Ermita desde antiguo, y así aparece en documentos de 1377, por ejemplo.

Lo cierto es que el gran impulso se lo dió una mujer, Caterina Bas, nacida en Jávea en el primer cuarto del siglo XIV, que decide retirarse a la vida contemplativa, instalándose junto a la ermita. La noticia más antigua que he encontrado es del 1 de julio de 1377 en que don Jaime, obispo de Valencia y hermano de don Alfonso, duque de Gandía y protector de la ermitaña, la autoriza a que en el Cap de la Ermita, donde llevaba una vida eremítica, pueda construir una capilla dedicada a San Antonio, junto a la casa "seu cellulam" que va a edificar en el mencionado eremitorio, pudiendo celebrarse misa en la misma.

Otro protector de la mencionada ermitaña fue el infante Martín, que en julio de 1387 le concede una renta de 210 sueldos anuales sobre ciertos censos y rentas que percibía de la partida del Real, para la salvación de su alma y la obra de la ermita.

El siguiente ermitaño del que tenemos noticia en la mencionada ermita fue Pau Mir, al que el 16 de enero de 1426 el baile general del reino encomienda el citado establecimiento, vulgarmente llamado ermita del Cap, con derecho a percibir sus censales y rentas, que podría dedicar a obras en el edificio (12). Este nombramiento fue ratificado por Alfonso el Magnánimo desde Valencia el 24 de enero de 1427 (13). Todo apunta a la formación de un patrimonio del citado centro religioso, cuyo monto desconocemos.

A mediados de siglo, 1450, Alfonso el Magnánimo renovaba la dotación hecha en 1387 por el infante Martín, pero esta vez en favor de la ermitaña Andrea de Rostoro, cuyas virtudes se elogian en el mencionado documento (14).

No debió de permanecer mucho tiempo al frente de la ermita, por cuanto el 11 de agosto de 1451 las autoridades reales comisionan a Antoni Llorens, portero real, para que vaya a la iglesia de San Antonio y ponga en posesión de sus rentas y derechos a Vicente Gil, notario, en nombre de Jaume Gil, notario de Alcoy, a quien se las había concedido el rey (15). Interesa destacar el calificativo de iglesia que le da el documento frente al de simple ermita, y aunque no fuera de hecho una iglesia, refleja la práctica de un culto más o menos frecuente y de un reconocido prestigio en la comarca, lo que la hacía el centro de devoción de muchos vecinos de Denia 
y Jávea, así como de sus donativos y legados. Este enriquecimiento y relativa prosperidad por la que atravesaría el eremitorio a los pocos años de su fundación explica el afán de los particulares por hacerse con el control de sus rentas, lo que consiguen, como se ha visto, gracias al favor real.

Pero hay más en torno a esta ermita. El cabo de San Antonio, al igual que su vecino San Martín, más al sur, son dos imponentes promontorios avanzados en el Mediterráneo, que sirven de excelente atalaya para controlar la navegación que costea el litoral valenciano. Durante toda la Edad Media -y en siglos posteriores- las costas del reino de Valencia fueron uno de los objetivos preferidos de los piratas y corsarios, y entre ellas las alicantinas, en particular las de La Marina, cuyo abrupto litoral propiciaba el refugio y los ataques por sorpresa a embarcaciones y poblaciones del litoral. Baste recordar las devastadoras incursiones llevadas a cabo por piratas berberiscos en el siglo XV contra Calp o Benidorm en varias ocasiones, que supusieron el cautiverio de muchos vecinos y una grave fractura en la demografía local (16).

Ello explica la instalación de un sistema preventivo de vigía y de avisos contra tales ataques, del que formaba parte la creación de una red de torres vigía, que aparecerá correctamente estructurada a partir del siglo $\mathrm{XVI}$. Pero en el Cuatrocientos vemos ya algunas de estas torres, como es la del Cabo de San Antonio, de la que hasta ahora no teníamos noticias tan antiguas, lo que permite retrotraer sus orígenes a los siglos medievales.

El mantenimiento de la torre y la ermita iban juntos, y según un documento de 1458 tenían como base la concesión de ciertas rentas hechas en el pasado por la Corona, en concreto la concesión hecha por Alfonso $\mathrm{V}$ a favor de Jaume Gil, con la condición de que tuviera ambas edificaciones en buen estado. Lo cierto es que el concesionario no cumplió su misión y en 1458 tanto la ermita como la torres "sien vengudes a total destrucció e ruyna", convirtiéndose en un lugar inseguro en el que nadie se atrevía a permanecer, ni el ermitaño ni los vigilantes.

Este abandono propiciaba cualquier posible ataque enemigo, por lo que las autoridades de Denia y Jávea, conscientes de la importancia estratégica de estas instalaciones piden a Juan II que tome medidas para su puesta a punto y salvaguarda. A esta petición respondió favorablemente el rey, convocando una reunión entre Jaume Gil y los síndicos de Denia y Jávea en presencia del baile general del reino, que debería escuchar las razones alegadas y disponer de los fondos necesarios para reparar la ermita 
y el cabo (17). Es la última noticia conocida para el periodo medieval de esta ermita del cabo de San Antonio, que se mantuvo en pie en épocas posteriores.

Hubo otras ermitas en la zona, y en el propio término de Denia tenemos una autorización de don Alfonso, duque de Gandía, a Joan Más y cuantos hagan vida eremítica con él en el castillo de Alambroy, para realizar edificaciones en dicha fortaleza (18). Ignoramos si tal proyecto se plasmó en una realidad concreta, pero testimonia el auge del eremitismo en Denia en el tránsito de los siglos XIV y XV, posiblemente en este caso imitando el modelo de la cercana ermita del cabo de San Antonio.

Otras ermitas localizadas en la Marina son la de Benissa, foco religioso para los habitantes del entonces extenso término, en el que se incluían lugares como Teulada, que contribuían económicamente al mantenimiento de la misma, tal como se desprende de la orden dada el 2 de septiembre de 1404 por el duque de Gandía, don Alfonso, a Guerau Eimerich para que haga comparecer al síndico de Teulada, con el fin de tratar sobre la contribución de dicha población a la ermita de Benissa. Más tarde, el 26 de junio de 1405 este aporte quedará fijado por el duque en la suma anual de 25 sueldos (19). El ermitaño pasa a convertirse practicamente en un vasallo más al servicio del duque, encargado de rezar por su persona, y la ermita en otra de las dependencias ducales. La caridad privada es sustituida por el estipendio público.

Otra ermita cercana, que plasmaba esta forma de religiosidad, se hallaba en Oltà, donde residía un ermitaño, Berenguer Llorenç, que vivía retirado en una celda, hasta que la intervención de unos vecinos de Calp y Benissa, que tenían tierras contiguas a la misma, comenzaron a molestarles y a estropear sus tierras y plantas, llegando a talarle los árboles, por lo que el duque de Gandía tuvo que intervenir en 1406 ordenando a dichos vecinos que no lo molestaran, so pena de ser castigados con una multa (20).

Como vemos, los testimonios de ermitaños y vida retirada son relativamente frecuentes, a pesar de lo escasas de las fuentes, que sólo se hacen eco de ellos en momentos o situaciones conflictivas.

También en tierras de la gobernación de Orihuela, al sur de la línea Biar-Villajoyosa, encontramos ermitas en las principales localidades con población cristiana. Las noticias conservadas son básicamente de edificios situados en un marco urbano o periurbano, en los alrededores inmediatos 
de la localidad. En ALICANTE A. Ramos menciona las de la Virgen del Lluch y la de Santa Ana, emplazadas en el sector oriental extramuros de la ciudad, donde surgiría el futuro arrabal Roig (21).

Otra noticia de la que sólo se conserva lo referente a su fundación es la que se refiere a la ermita de Santa Ana: "En 5 de jiner orde pera fer la Ermita de Santa Ana" (22), cuyo emplazamiento ignoramos.

La más famosa de todas las ermitas alicantinas fue la de Nuestra Señora de los Angeles, sita en un pequeño montículo, en el paraje del Plà del Bon Repós, en el camino que conduce a San Vicente. No hay noticias sobre su fundación, aunque la tradición, que recoge Viravens, la vincula al milagroso suceso del hallazgo de la Virgen por un leñador, siglos después de haber sido ocultada para evitar profanaciones de los musulmanes. Sucesos milagrosos como éste se repiten por toda la geografía regnícola. Se trataba, según el cronista alicantino, de una tabla de $70 \times 40 \mathrm{~cm}$, donde aparece la Virgen, de rostro moreno, sosteniendo al Niño en el brazo izquierdo y que estilísticamente entroncaría con las tablas sienesas del siglo XII de estilo bizantinizante, similar a otras muchas del mismo estilo que se reparten por toda la geografía valenciana, como es el caso de la Mare de Déu de Gracia, conservada en la iglesia de San Agustín de Valencia (23).

En ELCHE existían varias ermitas en el casco urbano de la villa. La más antigua de ellas parece que era la de San Jorge, edificada por el Consell en agradecimiento al citado santo y como conmemoración por la retirada del caudillo granadino Ridwan en el sitio que puso a Elche en 1331.

En 1435 llegó a la villa un ermitaño que solicitó al Consell que le construyera una vivienda junto a dicha iglesia, encargándose de su asistencia y mantenimiento. Para su edificación se dispusieron fondos de la iglesia, que en 1438 era dotada con una campana.

Esta ermita se situaba en la calle de San Jorge y era sufragánea de la parroquia. Dado que San Jorge era el patrón de la villa, su festividad era solemnemente celebrada con asistencia de las autoridades municipales y del clero de Santa María y EI Salvador.

También la ermita de San Jaime remontaría sus orígenes al menos al siglo XIV, ya que al igual que San Jorge, son santos característicos de la Corona de Aragón, de culto posterior a la incorporación de Elche al reino de Valencia. En esta ermita se reunió un Consell especial en 1408, y en 1438 se compraron unas ampollas de arena para medir el paso del tiempo 
y poder tocar las horas, colocando el Consel/ tres campanas en el reloj. Se localizaba en la calle de su nombre, esquina de la actual plaza de Abastos, y la fiesta anual corría a cargo de los caballeros.

Otra ermita urbana estaba dedicada a San Sebastián, en la calle Mayor, y quizá fuera erigida por el vecindario como testimonio de agradecimiento a este santo, abogado de la peste, mal que con frecuencia azotaba al Occidente bajomedieval.

El edificio era de una sola nave, con tres capillas laterales, y las noticias más antiguas que se conservan se remontan a 1489, en que el Consell prevee edificar una iglesia bajo la advocación de San Sebastián, situada en la calle Mayor, junto al hospital, pero al no haber fondos suficientes para terminar el proyecto el Consell dió 100 sueldos para dicho fin. Noticias posteriores de 1630 sitúan la fundación de San Sebastián en 1498, año en que quizá pudo terminarse y consagrarse el edificio.

También de fines del siglo XV es la ermita dedicada a San Antonio Abad, bendecida y consagrada en 1483 y emplazada extramuros, en el camino que de Elche conducía a Alicante (24).

ORIHUELA, cabeza de la gobernación y una de las principales ciudades del reino, era la urbe alicantina de mayor población y también la que contaba con una actividad eclesiástica más compleja y extensa, que culminaría con su erección como obispado en 1564 tras un largo proceso. Es también la localidad con mayor número de ermitas, insertas varias de ellas en el entramado urbano, y cuyas vicisitudes merecieron la atención de los cronistas locales, como Bellot en sus "Anales" o posteriormente Gisbert y Ballesteros (25).

Podemos comenzar este recorrido por las ermitas oriolanas refiriéndonos a la de Loreto (Lorito u Orito, según otros textos manuscritos), fundada en 1304 como capilla de un hospicio general por Sancha de la Torre y Brisuela, en una casa suya. En 1548 quedó agregada a la catedral como capilla de ésta (26).

La ermita de San Juan Evangelista es identificada por Gisbert con la que se llamaba de Santa Eulalia en 1286, siendo utilizada por los mercedarios hasta 1377, y pasando luego a ser iglesia del monasterio franciscano de San Juan Bautista (27). 
La de San Sebastián y San Roque estaba fuera de la ciudad, al mediodía, y se sabe que existía desde 1315. Más tarde fue ayuda de la parroquia del Salvador.

Junto al consistorio medieval, en la calle del Angel, se levantaba la ermita de Nuestra Señora del Rosario y San Juan Bautista, que desde 1274 a 1320 , mientras estuvo en poder de los templarios fue un oratorio bajo la advocación del angel guerrero San Miguel. Tras la disolución de la Orden del Temple pasó a ser ayuda de la parroquia del Salvador, servida por un sacerdote y un sacristán o ermitaño seglar, que se dedicaba a pedir limosna.

En una posesión de los señores de Bonanza, en el término oriolano, se levantó la ermita de Santa Ana, de la que Bellot dice que ya existía en 1440, y en donde residian algunos ermitaños, a cuyo frente estaba fray Umberto. En 1449 el Consell les cedió una noria para regar el huerto de la ermita. Como vemos, no era inusual que estos establecimientos dispusieran de una pequeña parcela de tierra que les procuraba el sustento cotidiano.

A mediados del siglo XV, 1449, y por iniciativa de Pere de Brizuela y Campomanes se erigió la ermita dedicada a Nuestra Señora de la Asunción y San Ambrosio, conocida también como ermita de la Corredera, y cuya delimitación era "rasante el arco de salida de la calle y a la casa y jardines de Brizuela sobre la acequia y los contiguos bancales que ésta regaba" (28)

De tamaño mediano, disponía de dos salas para albergar pobres peregrinos, por lo que también desempeñaba la función de centro asistencial. La multiplicidad de funciones era habitual en la época.

En los montes que rodean a Orihuela, en el rincón de Bonanza, junto a un manantial, se erigió la ermita de San Cristobal. Los eruditos recogieron la noticia de la edificación junto a la mencionada fuente por los romanos de un templo dedicado a Venus, y en 1493 se hallaron restos de lápidas e inscripciones que se supuso pertenecieron a dicho templo romano. Sea o no cierta la noticia, que sólo excavaciones arqueológicas ayudarían a descifrar, lo que sí queda manifiesto es la sacralización del terreno, no sabemos si para los fundadores, pero sí al menos para la historiografía posterior. La existencia de manantiales y las posibilidades de cultivo propiciaban y garantizaban la continuidad de estas experiencias eremíticas, próximas a los núcleos de población, pero lo suficientemente aisladas para 
garantizar el recogimiento necesario, a la vez que proyectaban su ejemplo sobre los vecinos de la cercana urbe.

Tampoco en este caso podemos precisar la cronología, aunque Bellot da la noticia de que en 1408 vivía allí una pequeña comunidad de siete ermitaños. Como en otros casos, la fama de estas gentes, les hizo contar con el apoyo de las autoridades municipales, que este año prohibían que se talasen árboles o metieran ganados en el término de la ermita. En 1412 el mensajeros de los jurados ante la corte papal, Guillem Pérez, consiguió diversas gracias espirituales para los particulares que favorecieran la ermita.

Estos años de principios del siglo XV corresponden a una etapa de expansión del eremitorio, sobre el que se vuelcan favores y gracias, lo que despertó el recelo del clero secular, que veían perder beneficios, como pone de relieve la prohibición lanzada en 1411 por el arcipreste de Santiago de que se celebrara misa en el santuario sin su permiso. Esta prohibición fue recurrida y revocada por el vicario oriolano a petición de los mayordomos. Ello prueba que en torno a la ermita debió surgir una cofradía, de la que nada sabemos, salvo que ese mismo año se consiguió indulgencia "a pena y a culpa" para los cofrades.

La ermita fue reedificada o construida de nuevo a partir de 1483 a iniciativa del subdiácono Jaume Ferrer Camball (29).

Otras dos ermitas del área orcelitana son la de Nuestra Señora del Socorro, a pocos kilómetros de la ciudad, que parece emerger a la luz pública a finales del siglo $\mathrm{XV}$, pero cuyo culto se difundió a causa de una serie de milagros obrados por su imagen en 1510 (30).

En la entonces aldea de Cox se daba culto a la Virgen de las Virtudes en una ermita, que a fines del Medievo era marco de una popular romería comarcana, en la que incluso participaban los mudéjares. Pero no hay más noticias de todo ello.

Es muy interesante constatar la existencia en Orihuela de un eremitorio o beaterio consagrado a San Miguel, erigido en una montaña de los alrededores de la ciudad. En 1445 el Consell autorizó a algunas mujeres a que hicieran vida retirada como beguinas en unas celdas que habían construido junto a esta ermita. Adoptaron la regla de las clarisas y eligieron como superiora a Giomar Masquefa, esposa de mossén García de Heredia, comendador de Aledo y vecino de Orihuela (31). La reunión de mujeres laicas en este tipo de establecimientos refleja una peculiar forma de espiri- 
tualidad femenina, al margen de las reglas oficiales, por lo que no siempre fueron bien vistas por las autoridades religiosas. Es muy interesante el paralelo existente entre este beaterio y el de Llíria, de similar composición femenina, emplazado también en la cima de un cerro y dedicado a San Miguel. En el aire queda la pregunta de las influencias que pudo tener sobre el fundado en Orihuela.

De todas las emitas del término oriolano la más famosa fue la de San Ginés de Orihuela, localizada en un paraje marítimo delimitado por el puerto seco del Lobo, la peña de los Cuervos y el Portichol de Romanos o cañada de la Fosa. El complejo de edificaciones estaba integrado por una casa-ermita y una torre defensiva, así como por un huerto. Era la sede de la cofradía del mismo nombre, a la que nos referimos en otro apartado.

El Consell de Orihuela ejercía cierta tutela sobre la ermita y le dispensaba sus beneficios, nombrando en ocasiones al encargado de su custodia. Sabemos que en 1407 se había encomendado dicha tarea a Pere Martí, cuya hacienda había sido arruinada y había gastado en la ermita el dinero que le quedó. Pero la ermita fue saqueada por cinco ballesteros, que arrojaron de ella a Martí, por lo que el Consell intervino a su favor para castigar a los malhechores (32). Otro ejemplo de esta protección municipal es la autorización dada por los jurados en 1436 para que se recolectaran limosnas por toda la Gobernación con destino a San Ginés(33).

\section{LAS COFRADÍAS.}

Las noticias que teniamos sobre cofradías medievales en tierras alicantinas aparecian difusas en obras de carácter general, como era el caso de las historias locales de Alcoy, Elche, Orihuela, etc. y pocos estudios se ceñían de forma monográfica a las propias cofradías, pudiendo citarse como pionero la publicación por $\mathrm{V}$. Martínez Morellá, que fuera cronista oficial de Alicante, de los capítulos de la cofradía alicantina de San Nicolás (34), o el de Mercedes Gallent sobre las cofradías de Biar y Alcoy (35), o el de A. Cuenca sobre las cofradías de Gandía y Denia dedicada esta última a Santa María (36). Recientemente J. Sánchez Herrero ha realizado una síntesis del panorama de las cofradías alicantinas y valencianas (37), obra que, junto con las arriba citadas y la documentación de archivo nos sirve como marco guía en esta síntesis. 
En cuanto a la tipología de las cofradías, Sánchez Herrero comienza hablando de las cofradías gremiales, es decir, "gremios de artes y oficios que se desdoblan en una cofradía", pero en nuestro trabajo nos centraremos preferentemente en las de carácter religioso, que son las que predominan en tierras alicantinas. Recordemos que la industria en el Alicante medieval tuvo un carácter modesto, salvo, quizá, el caso de Orihuela, y las corporaciones de oficios hacen su aparición tardíamente, estando todavía por estudiar su desarrollo.

Las cofradías estuvieron bajo la advocación de los santos o de la Virgen. Las cofradías con el nombre de Santa María son las más numerosas y las encontramos en Alcoy, Alicante, Biar, Denia, Cocentaina, Callosa de Segura y Orihuela (Santa María de Monserrate). La Virgen del Rosario tuvo su cofradía en Orihuela, mientras que a la Sangre de Cristo y a la Tercera Orden se dedicaron otras dos cofradías en Orihuela.

Esta advocación a la Virgen, igual que la de los santos, derivaba en ocasiones de ser la titular de la parroquia o iglesia donde radicaba la cofradía. Es el caso de la de San Nicolás en Alicante, San Ginés en Orihuela, etc. Otros santos titulares de cofradías figuran en el devocionario popular de la época, como San Blas y, sobre todo, el popular San Jorge en Alcoy y Orihuela.

No aparecen en tierras alicantinas cofradías exclusivamente clericales, sino que reúnen en su seno a distintos grupos sociales. Tampoco hay noticias de cofradías de enfermos (ciegos, leprosos, etc.) o de conversos de judío.

Predominan las cofradías devocionales, vinculadas a la veneración de un determinado santo, a los que acabamos de referirnos. Entre las cofradías unidas a un hospital puede citarse la de Santa María de Alcoy (1494), que enterraba a los pobres que fallecían en el hospital.

Cronológicamente la etapa de fundación de estas cofradías se centra en el siglo XV, siguiendo la tendencia general que se aprecia en todo Occidente, "el siglo de apogeo de las cofradías" (38). En la misma diócesis de Cartagena-Murcia vemos surgir entre los años 1468 y 1473 diez nuevas cofradías en la ciudad de Murcia (39), respondiendo así al deseo de las gentes de asociarse en instituciones de fraternidad que les resuelvan aspectos de la vida religiosa y social. 
Debemos comenzar señalando que en los siglos medievales no tenemos por el momento noticias de cofradías profesionales en Orihuela, y las noticias conservadas son todas de cofradías devocionales 0 asistenciales.

A través de las noticias de Bellot y de Gisbert y Ballesteros se documentan al menos siete cofradías, lo que coloca a esta ciudad a la cabeza de las localidades alicantinas en cuanto al número de estas instituciones, corroborando la teoría de una mayor abundancia en las ciudades, donde había más población, que en los pequeños núcleos (39). La más antigua sería la del Rosario, de la que sabemos que existía en 1281. Ninguna noticia más se ha conservado hasta 1510, en que se fundó una archicofradía del mismo nombre en Santo Domingo, suscitándose un pleito entre ambas, hasta que en 1512 Julio II dispuso que sólo hubiera una cofradía de este nombre en ambos templos y con los mismos privilegios (40).

La cofradía de la Preciosa Sangre de Cristo se fundó en 1411 en la iglesia parroquial de Santa Justa, a raíz de la visita a la ciudad de San Vicente Ferrer. Fruto de sus exaltadas y apocalípticas predicaciones surgió esta cofradía de penitentes disciplinantes, que se azotaban las espaldas desnudas entre rezos y cánticos. En ella fueron admitidas las mujeres (41). Es la única cofradía relacionada con la celebración e imitación de la Pasión de Cristo, que son raras en el reino de Valencia en los siglos bajomedievales, en contraste con Castilla, donde el culto a la Vera Cruz aparece en fecha más temprana (42). No falta, sin embargo, en tierras valencianas una cofradía de la Vera Cruz, en Xàtiva, en fecha tan temprana como 1333, explicable quizá por la propia devoción de los reyes hacia la cruz, la castellana reina doña Leonor y Pedro el Ceremonioso.

En el convento de la Merced se constitye en 1494 la cofradía de San Blas, mártir, en una capilla que desde 1309 había dedicada al mencionado santo. El papa Alejandro VI aprobó la bula de constitución de la nueva cofradía. $Y$ desde 1689 hasta 1731 los músicos oriolanos tomaron como patrono a San Blas (43).

A mediados del siglo XV, en 1449, se establece en el convento de Santa Ana la Tercera Orden de Penitencia de San Francisco. En el santuario de Monserrate se crea la cofradía bajo la advocación mariana de este nombre, siendo confirmada por Sixto IV dicho año. 
La cofradía de San Jorge agrupaba a los caballeros de la ciudad y su origen no está precisado, aunque hay que remontarlo al siglo XIV, tras la incorporación de Orihuela a la Corona de Aragón, en cuyos Estados dicho santo gozaba de particular devoción. Sus estatutos fueron modificados en 1402, y Bellot recoge la noticia de que el cofrade que perdiera su caballo en alguna escaramuza vería su importe reembolsado por la cofradía. La fiesta anual de la cofradía era famosa en la ciudad y sus alrededores, hasta el punto de desplazarse numerosos caballeros de la vecina Murcia para participar en la misma (44). Estamos seguros que en dichas celebraciones no faltarían los ejercicios y espectáculos de caracter paramilitar, donde los jinetes oriolanos exhibirían sus excelencias para deleite y disfrute de los asistentes. La fiesta era el primero de mayo y todos asistían con sus mejores galas.

De las cofradías oriolanas la más famosa fue la de San Ginés, cuya sede era la ermita consagrada a dicho santo, a la que se añadía una torre de vigilancia frente al mar. Debemos tener presente lo extenso del término oriolano y su baja densidad de población, sobre todo en la costa, lo que explica los riesgos de la zona ante los desembarcos y correrías de piratas y corsarios norteafricanos y granadinos. Por tanto, una de las finalidades de la cofradía sería la defensa del territorio ante una incursión armada enemiga.

Acerca de sus orígenes, como sucede en otros casos, polemizaron los eruditos locales de antaño, siendo recogidas sus hipótesis por Gisbert. Para Bellot la cofradía era muy antigua y dice que sólo pertenecían a ella los caballeros, lo que estaría en consonancia con el carácter militar de la edificación. Esplugues y Fabián de Montesinos, aún cuando reconocen la fecha de constitución, no dudan en enlazarla con una capilla dedicada en tiempos visigodos a San Ginés, en la iglesia de San Julián, luego de Nuestra Señora de Monserrate. Por su parte Ramírez la vincula al templo de Monserrate y da el año 1419 para su fundación, participando en ella el justicia y jurados de la ciudad. La componian los labradores ricos que poseían caballos y yeguas, los molineros, arrendatarios y tratantes de ganado. Agrupaba, por tanto, a personas que disponían de una desahogada posición económica, capaces de poseer caballo, y que presumiblemente formarían parte de la oligarquía local.

Esta opinión de Ramírez es aceptada por Gisbert (45) y por autores posteriores (46). Lo cierto es que caso todas las cofradías oriolanas se fundan en el siglo XV coincidiendo con un renacimiento de la fe popular en la ciudad durante esta centuria, reflejado en múltiples manifestaciones, como el culto a Nuestra Señora de Monserrate o a la Virgen del Socorro, ambas patronas de Orihuela. 
La ermita y la cofradía de San Ginés contaron con el apoyo y las subvenciones del Consell de la ciudad para la realización de obras en los edificios. Incluso al santo se le atribuyeron influencias en las victorias napolitanas de Alfonso el Magnánimo, lo que le valió diversos legados. En 1445 eran mayordomos de la cofradía miembros de las familias Galbe, Pérez Vaillo y Villafranca, todas ellas del patriciado local.

Conviene recordar la importancia que no lejos de Orihuela, en el vecino reino de Murcia, frente al Mediterráneo, tras la manga del Mar Menor, y en unas condiciones ambientales similares, se levantò el monasterio de San Ginés de la Jara, cuyo culto tiene antecedentes anteriores a la dominación musulmana, pero que alcanza a partir del siglo XV una enorme popularidad en toda la región e incluso en la vecina Orihuela, sin olvidar la devoción de los mudéjares hacia el milagroso santo, cuya romería se celebraba el 25 de agosto y atraía a gran número de gentes (47).

El parelelismo entre ambas fundaciones es muy notable en ciertos aspectos, como la dedicación, el emplazamiento cerca del mar, su carácter paramilitar como defensa de una zona poco poblada frente a incursiones marítimas enemigas. Puede pensarse en la fundación de la ermita-cofradía de Orihuela como una imitación de la existente en tierras murcianas y un aumento de la devoción hacia el santo paralelo en ambas instituciones en el siglo XV. La distancia no era mucha y las noticias de los prodigios de uno $u$ otro templo se difundían rápidamente en estas tierras fronteras, pero permeables a las ideas y a las devociones populares. No olvidemos que Orihuela formaba parte del obispado de Murcia.

\section{Cofradías en Alicante.}

En Alicante existen en la Edad Media dos cofradías, una por cada parroquia, la de San Nicolás, la más antigua, y la de Santa María, posterior, de finales de la Edad Media.

Nuestras noticias sobre las cofradía de San Nicolás proceden de la publicación en 1964 por V. Martínez Morella, cronista a la sazón de la ciudad de Alicante, de un opúsculo con los capítulos de la citada cofradía insertos en la "Crónica de Alicante" del deán Vicente Bendicho (1640) (48). La mala comprensión y lectura de la documentación original explica la deficiente transcripción de los capítulos de la cofradía.

El 10 de abril de 1402 Martín el Humano, a petición de la cofradía de San Nicolás, lo que hace es confirmar sus capítulos. El momento exacto 
de la fundación es imposible precisarlo, ya que ningún dato permite establecer suposiciones; quizá fuera en el siglo XIII o primera mitad del XIV. Lo cierto es que funcionaba a mediados del siglo XIV, antes de la guerra de los dos Pedros, habiendo sufrido graves perjuicios a raíz de la guerra, como consecuencia de la desorganización de la propia villa de Alicante. La restauración de la paz y del territorio en el último cuarto del siglo XIV afectó también a la vida diaria de los alicantinos, a sus instituciones particulares, y una prueba de ello sería la confirmación por el monarca de los capítulos de esta cofradía. Veamos cuáles eran los deberes y obligaciones de los cofrades.

1. Cada sábado, en honor de Dios y la Virgen María, durante la misa mayor se quemarían ocho cirios en el altar de San Nicolás, que serían encendidos y apagados por los mayordomos.

2. Estos cirios arderían en el altar de San Nicolás o delante de él en la misa del Gallo y en la matinal del día de Navidad, el día de Pascua de Resurrección y de quincuagésima, el de San Nicolás y las vísperas durante la misa mayor, encendiéndolos y apagándolos los mayordomos.

3. Si un cofrade muere se haría sonar la campanita por la villa para que todos supieran su fallecimiento. Lo mismo si muere su hijo/a, o un sobrino que hubiera sido criado por cofrades y su mujer, debiendo acudir todos los cofrades al entierro. En caso de no hacerlo, sin causa justificada, debería abonar como multa una libra de cera para la caja de la limosna de la cofradía.

4. Si muere mensajero o sirvienta del cofrade deberían acudir al entierro ocho cofrades con otros tantos cirios, bajo la citada pena en caso de no hacerlo.

5. Cada cofrade debía rezar por el alma del cofrade muerto un día después del óbito cien padrenuestros y otras tantas avemarías, quedando en la conciencia de cada uno la responsabilidad de decirlas o no, o bien decir una misa de requiem si no pudiera hacerlo.

6. Si algún cofrades o su hijo/a se casa, durante la noche de vela todos los cofrades debían ir a la iglesia de San Nicolás para proveerse de su cirio, y desde aquí se dirigirán a la casa del cofrade contrayente para hacerle honor, según la costumbre. El que no pudiere acudir sin causa justa pagaría una libra de cera a la caja de la limosna de la cofradía. 
7. Si algún cofrade cayera cautivo se darán como ayuda de su rescate treinta libras, y se depositarían en la caja de la limosna doscientos sueldos para su rescate.

8. Si algún cofrade por vejez o debilidad o por caer en la pobreza necesita dinero, los mayordomos le ayudarían en secreto a sobrevivir.

9. En caso de enfermedad de un cofrade sería velado durante la noche por cuatro cofrades que se turnarían, no dejándole hasta que hubiera mejorado o fallecido. El que no acudiera debería pagar una libra de cera.

10. Si un cofrade se va de viaje y cae enfermo a una jornada de Alicante y se tienen noticias de ello, que cuatro cofrades acudan a donde esté el enfermo y lo acompañen hasta que mejore o muera, o que lo lleven a su casa, corriendo la caja común con el gasto de los cuatro cofrades.

11. Si un cofrade riñe con otro compañero, que los mayordomos y otros buenos hombres de la cofradía traten de apaciguarlos y restablecer la paz entre ellos. Si uno no quisiera respetar esa amistad, que se le expulse de la cofradía.

12. Si un cofrade no obedece las disposiciones justas y honestas ordenadas por los mayordomos y no guarda reverencia y honor a su compañero, como se ha ordenado, sería expulsado de la cofradía de manera definitiva.

13. La víspera de la fiesta de San Nicolás todos los cofrades acudirían a las vísperas, quemando todos los cirios ese día y en la misa del día del santo. Tras la fiesta se celebraría una comida a la que asistirían los cofrades y todos los asistentes a los oficios sagrados, celebrándose el ágape en una casa apropiada. También serían invitados al banquete los pobres que se encontraran en la villa, que serían bien servidos por amor de Dios y se les entregaría dos dineros.

14. El día de San Nicolás se elegirían dos hombres buenos por administradores y mayordomos, con la misión de registrar todos los sucesos de la cofradía ese año. Tendrían poder de desterrar a los cofrades y hacer cumplír las penas mencionadas en anteriores capítulos. Eran los encargados de custodiar el paño ("el drap", que podemos interpretar como bandera), cirios, moneda y todos los restantes bienes de la cofradía y su limosna, obligando a los pasados regidores como a los otros cofrades a que no tomen en préstamo dinero de la cofradía. 
15. Al día siguiente de San Nicolás se celebrarían misas de requiem por el alma de los cofrades difuntos, a las que debían acudir todos los cofrades. Se haría oferta de pan, vino y velas, dándose a cada sacerdote un sueldo por la misa, siempre que la dijeran. Estos sacerdotes deberían bendecir el cementerio.

16. Durante esos días los mayordomos entregarían diez sueldos a los pobres vergonzantes de la villa.

17 Al día siguiente de la festividad de la Virgen se celebrarían varias misas con toque de campanas por el alma de los/las cofrades (es la única vez que se menciona a las cofrades femeninas, "les confrareses") muertos. La víspera habría una comida para los cofrades que asistan, dándose a los sacerdotes que digan misa un sueldo. El que no vaya pague una libra de cera para la limosna.

18. Los mayordomos salientes deberán rendir cuentas el día de San Nicolás de su gestión durante ese año, así como del dinero que había en la limosna y las penas impuestas a los cofrades. Respondían con sus bienes de dicha gestión económica.

19. Todos los miembros de la cofradía jurarían obediencia y permanecer bajo el mandato de la cofradía y sus mayordomos, de sus capítulos, cumpliendo todo lo que se mandare.

20. Cada cofrade abonaría una cuota semanal, los domingos, de un dinero, para sostener la limosna de la cofradía; de un dinero para la comida y las misas el día de San Nicolás; dos sueldos el día del santo para la comida. El dinero lo recibirían los mayordomos, debiendo rendir cuentas el día de San Nicolás.

21. Los que quisieran pertenecer a la cofradía abonarían como cuota de entrada cinco sueldos y medio, más un cirio de dos libras de peso.

22. Se hace partícipes de todas las limosnas, misas y beneficios de la cofradía al rey, a la reina y sus hijos "perque Déu exalte la Real Corona de Aragó".

23. Cada año se reuniría capítulo de la cofradía el día de Santa María, el de Corpus Christi y ocho días después de la festividad de San Nicolás, con el fin de ordenar lo necesario para la fiesta, siendo invitado el justicia de la villa. 
Así pues, vemos unos capítulos en los que predominan los fines asistenciales y devocionales, con un contenido -al que nos referiremos en otro lugar- similar al de muchas otras cofradías. Durante muchos años, la de San Nicolás fue la única cofradía alicantina. Recordemos que el mencionado santo era el patrón de Alicante, aunque muy pocos eran los alicantinos de la época que llevaran su nombre.

Lo cierto es que con esta refundación por Martín 1, la cofradía sale fortalecida, y cabe pensar que también la parroquia de San Nicolás, que mantenía una fuerte rivalidad con la más antigua de Santa María. Pero el desplazamiento socio-económico de la villa hacia la "Vila Nova" beneficiaba a San Nicolás en detrimento de Santa María, que quedaba más excéntrica. El nombramiento, luego fallido, de San Nicolás como colegial por el obispo de Cartagena, Pablo de Santa María, muestra esta primacía eclesiástica de la mencionada parroquia.

La única noticia conservada en el siglo XV de esta cofradía es una autorización el 12 de marzo de 1487 de Fernando I, a petición de los mayorales y capítulo de la cofradía, a que sus fondos puedan comprar trigo destinado a uso exclusivo de los cofrades. Ante el temor de éstos de que los jurados de Alicante pudieran apoderarse de este trigo, el rey les prohibe que tomen dicho trigo, y si por necesidad hubieran de hacerlo, tras decidirlo el Consell, que se lo abonen a la cofradía primero. También autorizó a los cofrades a elegir anualmente un prior de los presbíteros de dicha cofradía, con las mismas prerrogativas que los laicos, lo que pone de manifiesto el éxito de la institución y una afluencia de clérigos lo suficientemente numerosa para reclamar un representante, con lo cual la cofradía adquiere ya un carácter mixto, laico-eclesiástico.

\section{Otras cofradías.}

Ya vimos como en Orihuela el siglo XV es la centuria en la que comienzan a proliferar las cofradías, que ya en los tiempos modernos alcanzarían su máximo desarrollo. También en Alicante se puede apreciar este crecimiento de la devoción popular y su plasmación en una nueva cofradía, que fue autorizada por Juan II, rey de Navarra y lugarteniente general del reino en ausencia de Alfonso el Magnánimo, en 1446 con el doble carácter de cofradía y limosna bajo la advocación de Santa María. Por una noticia de 1454 sabemos que a ella se había incorporado mucha gente de la villa, pero pronto surgieron tensiones con el párroco de Santa María, que ponía trabas a la celebración de las vísperas y misas de los cuatro aniversarios que se realizaban anualmente por los cofrades difuntos. La 
pérdida de poder e influencia sobre los fieles, razones económicas de estipendios, etc. no eran ajenas a estas rivalidades y enfrentamientos. El 6 de enero de 1454 Alfonso $V$, al margen del recurso que pensaba presentar al obispo de Cartagena, ordena al cura de Santa María que no se entrometa en las misas de la cofradía (50). Es la única noticia que ha quedado de esta cofradía.

Existió otra cofradía bajo la advocación de Santa María en CALLOSA DE SEGURA, descubierta para la historia gracias al encargo hecho el 3 de julio de 1459 por Juan II a Joan Roig, de Orihuela, de que resuelva la causa de apelación interpuesta por dicha cofradía a una sentencia del lugarteniente del gobernador de Orihuela en el pleito mantenido con Domingo Tribes (51).

En COCENTAINA, a instancias de los jurados y vecinos de la villa, la reina Violante, su señora, aprobó los capítulos de la nueva cofradía que se constituyó el 15 de abril de 1391 bajo la advocación de Santa María, titular de la iglesia parroquial, como en tantas otras localidades del reino.

Los capítulos de la cofradía fueron insertos por Fullana en su "Historia de Cocentaina" (52), por lo que no creo oportuno su repetición. Lo que interesa destacar es que su contenido es casi idéntico al de la cofradía alicantina de San Nicolás, aunque aquí aparecen algunas peculiaridades propias de la situación fronteriza de Alicante, como es la posible cautividad de sus miembros.

En general todas estas cofradías alicantinas bajomedievales tienen un marcado carácter laico, ya que sus promotores son las autoridaté y vecinos locales, siendo la autoridad real o señorial la que aprueba su constitución. En Denia el 15 de junio de 1405 don Alfonso, duque de Gandía, aprueba los estatutos de la nueva cofradía de Santa María, mientras que el 4 de agosto de 1494 Fernando el Católico hacía lo propio con las cofradías de Biar y de Alcoy, ambas también bajo la advocación de "nostra senyora la gloriosa Verge Maria" (53). La iniciativa en todas ellas partió del justicia, jurados y Consell de las respectivas villas. Sus objetivos básicos eran enterrar a los difuntos y ayudar a los enfermos y necesitados, lo que da un predominio a las actividades sociales, sin olvidar, claro está, las devocionales. Por lo demás, predominan en ellas los laicos, aunque como vimos en la de San Nicolás de Alicante, no faltaron los religiosos. 
Por no hacer excesivamente largo el trabajo no desarrollo en detalle los capítulos de las cofradías de Denia, Biar o Alcoy, que irán apareciendo al hablar de la organización de estas cofradías.

\section{ORGANIZACIÓN Y REGLAMENTACIÓN DE LAS COFRADÍAS.}

Tomando como punto de partida los estatutos de las cofradías mencionadas y a pesar de que las separa la cronología de un siglo, pueden establecerse unos puntos comunes en todas ellas, ya que sus fines son los mismos, y la caridad y la religión van a presidir sus actividades.

\section{Condiciones de entrada.}

El ingreso a la cofradía viene condicionado por una serie de exigencias especificadas en los propios estatutos, lo que hace de las mismas unos organismos restringidos.

Una condición básica para ser cofrade era la de ser persona honrada, honesta y de buena fama pública (de bona fama, honesta vida e conversacio), que debía ser comprobado por el prior, mayoral, consellers y cinco cofrades en la de Santa María de Denia. En Cocentaina se prohibía la entrada a los hombres y mujeres de vida licenciosa, mientras no enmendaran su conducta, pudiendo ser expulsados por pública deshonestidad. Estos requisitos no los encontramos en las cofradías de Alicante, Biar o Alcoy.

Respecto al número de miembros de la cofradía, por lo general no suelen ser restrictivas, pudiendo ingresar quien lo solicite y sea aceptado, aunque en la de Cocentaina se fija un tope máximo de cien personas, entre hombres y mujeres, ya que las cofradías alicantinas presentan un carácter mixto en cuanto a sexos se refiere.

En la cofradía de Santa María de Denia se exigía la residencia en la villa, condición que no aparece en las otras, aunque se supone que sus miembros eran vecinos de sus respectivas localidades.

Para formar parte de la cofradía se requiere el pago de una tasa, lo que en principio podría interpretarse como una limitación a quienes no poseyeran una cierta posición económica, aunque en realidad estas cantida- 
des no son muy elevadas; hay cofradías "baratas", como las de Alcoy o Biar, que sólo cobran tres sueldos de cuota inicial, la de San Nicolás de Alicante donde pagan cinco sueldos y medio y un cirio de dos libras de peso, hasta las más caras de Cocentaina y Denia, que cobra once sueldos de cuota de ingreso. En esta última se dan diez sueldos a los mayorales y uno al andador, y, al ser admitidos, otros diez sueldos a los mayorales y dos al andador. Todos los cofrades son anotados en un libro, que conserva el escribano, tachándose el nombre al fallecer.

Si alguna persona al morir solicitaba ser admitido en la cofradía debía pagar también una cuota, que oscila entre los 10 sueldos de Alcoy y Biar, a los 100 que se exigían en la de Santa María de Denia.

El incumplimiento de las normas y capítulos de la cofradía, el mantener clara enemistad con otros compañeros, podía suponer la expulsión de la institución, como sucedía en la de San Nicolás de Alicante.

Derechos y deberes de los cofrades.

Las cofradías tienen una clara función religiosa y caritativa, como es el caso de Alcoy y Biar, donde enterrar a los muertos se convierte en el objetivo preferente en su fundación. Todos los cofrades tienen derecho a ser asistidos, cuidados y velados en sus enfermedades por los otros cofrades, así como a percibir honrras fúnebres tras su muerte, acudiendo al entierro revestidos con los distintivos de la cofradía. Los cofrades eran convocados al toque de una campanita para asistir a las exequias del difunto, al que acompañaban portando cirios, desde su casa a la iglesia y desde aquí al cementerio.

Si algún cofrade caía en el estado de pobreza, la cofradía le ayudaba en sus necesidades materiales, en algún caso, como en Alicante, de forma secreta, evitando de este modo hacer público su difícil situación económica.

Otras obligaciones piadosas eran el rezo de cierto número de oraciones por los cofrades muertos (cien padrenuestros y avemarías en Alicante), así como la asistencia a los actos determinados en los estatutos, como era la misa el día de la festividad del titular, quemar cirios en el altar de la Virgen o del Santo bajo cuya advocación estaba la cofradía, asistencia a las misas de requiem, a procesiones o a la misa del sábado en Biar. 
También los cofrades de San Nicolás debían asistir en las bodas de los hijos/as a las vísperas del matrimonio, acompañando a los contrayentes con cirios.

Una particularidad de la cofradía alicantina citada era la de ayudar al rescate del cofrade que cayera en cautividad.

Desde el punto de vista moral, el cofrade debía mantener unas pautas de conducta honestas en público y en privado y respetar los capítulos de la cofradía, así como mantener la paz y la armonía con sus compañeros, ya que de lo contrarío se le amonestaría, primero por el prior, y en caso de reincidencia lo sería por el prior y los mayorales, y de haber una tercera vez por el prior, mayoral y consellers, hasta su expulsión definitiva si no obedecía. Todo ello en la cofradía de Santa María de Denia, donde se consideraban como mals vicis, axí como esser omicidi, usurer, adúlter, concubinari, fornicador, embriach, ladre, tafur, acoltellador o dient mal de Nostre Senyor Déu o de Nostra Dona Santa Maria, o el que hablase mal de la cofradía o de sus ordenanzas (54).

El incumplimiento de estas obligaciones suponía el pago de unas multas, por lo general una determinada cantidad de cera, que variaba según cada cofradía y que se destinaba al fondo común.

Los cofrades tenían también unas obligaciones económicas, que se iniciaban en el momento de su inscripción en la cofradía, como ya vimos. Además, abonaban cada año otras pequeñas cantidades de dinero en determinadas fechas y circunstancias: en la de San Nicolás de Alicante era una cuota semanal de un dinero, pagadero el domingo y destinado a mantener la limosna de la cofradía; otro dinero para la comida y misas el día de San Nicolás, y dos sueldos el día del santo para la comidad. En Alcoy y Biar era de dos dineros en las cuatro festividades principales que celebraban estas cofradías: la Anunciación de la Virgen (25 de marzo, día de la Encarnación), la Asunción (15 de agosto), la Virgen María de septiembre ( 8 de sptiembre) y la Presentación de la Virgen ( 2 de febrero). También en Denia en cada una de estas cuatro festividades se pagaban 6 dineros, siendo expulsado aquel cofrade que dejara de abonarlos durante dos años consecutivos sin razón justificada.

El lugar de reunión de la cofradía era la iglesia parroquial u otra específica, como la de San Nicolás en Alicante, en alguna de sus capillas, que en Alcoy o Biar era la capilla mayor. Los cofrades se encargan de embellecer, mantener y reparar los altares de sus respectivos patronos, colocando 
ornamentos, lámparas, cirios, etc. Este altar o capilla es el marco donde la cofradía practica la caridad pública con los pobres de la villa una vez al año, repartiéndoles pequeñas cantidades de dinero.

Por lo general las cofradías tenían sus propios clérigos, que se encargaban de realizar las funciones religiosas: misas, administración de los sacramentos, entierros, etc. lo que en algunos momentos engendró tensiones con el clero parroquial, celoso defensor de sus derechos religiosos y económicos.

En la cofradía la confraternidad es uno de los principios fundamentales, que hace a todos sus miembros copartícipes de unas obligaciones y derechos, en los que priman la caridad, la asistencia benéfico-social y la piedad, pero también un ambiente de gran familia, en el que no faltan los actos sociales de carácter colectivo, en los que participan todos los cofrades, como son las elecciones de cargos o los banquetes anuales que reunen a todos los miembros en torno a una mesa para festejar al santo patrón $u$ otro evento. En Alicante se celebra tras la fiesta de San Nicolás y en él están presentes cofrades, clérigos y los pobres de la villa. La caridad aparece, una vez más, como guía de sus actos, privados o públicos. También había otra comida la víspera de la fiesta de la Virgen. No hay noticias de estos ágapes en otras cofradías.

Organización administrativa y económica.

Las cofradías se gestionan mediante una colegialidad y una elección anual de los cargos, tratando de evitar el monopolio del poder en unas mismas manos.

El órgano de gobierno básico es el capítulo, reunido anualmente y al que asisten todos los cofrades. La reunión era en el local social de la cofradía, generalmente en las iglesias que hemos mencionado. Este capítulo tenía lugar varias veces al año: en Alicante los días de Santa María, del Corpus Cristi y ocho días después de San Nicolás; en Cocentaina el 15 de agosto (la Asunción), y el 2 de febrero (Presentación); en Alcoy y Biar "tantes quantes vegades sera necessaria", y en Denia al día siguiente de la Asunción. Coincide, como se ve, con las grandes fiestas marianas. Los motivos de estas reuniones eran tratar de todos los asuntos concernientes a la cofradía. 
El cuerpo rector de la cofradía está integrado por varios miembros. El prior aparece sólo en la de Denia y es un clérigo, que durante el año de su mandato será el regidor de la cofradía, con el consejo y ayuda de los mayorales y consellers.

Los mayorales de las cofradías de Alcoy y Biar son tres. El procedimiento electivo es el siguiente: cada uno de los mayorales designa a cuatro cofrades y el escribano a uno; de los trece candidatos se sacan tres a suertes, que serán los mayorales; siendo consejeros los tres restantes. En Cocentaina se elegían los mayorales por mayoría de cofrades. En Alicante eran dos los mayordomos, elegidos el día de San Nicolás. En Denia también eran dos laicos, elegidos por el capítulo de cofrades.

No tenemos noticias de que estos mayorales percibieran salario por su gestión, salvo en Denia, donde perciben 40 sueldos cada uno, destinados a comprar la gramalla y el capuchón de la cofradía, de lo que se deduce que había unos vestidos que distinguían a los miembros cofrades, o al menos a sus directivos.

Las funciones de los mayorales son muy variadas, como organizar los turnos para velar por los enfermos o llevar el féretro de los hermanos fallecidos, poner paz entre los cofrades enfrentados, sancionar a los transgresores de los capítulos de la cofradía. Una parte básica de su trabajo era la administración económica de los bienes de la cofradía, bien en metálico, bien en cera. En Biar y Alcoy controlaban la caja de la cofradía, que se cerraba con tres llaves, en posesión de cada uno de los mayorales, no pudiendo abrirse sin la presencia de los diez consejeros.

Los mayordomos salientes debian rendir cuentas de su gestión durante el año anterior, en un plazo de tiempo que oscilaba desde un día a un mes tras su elección, y en Alicante del dinero existente en la limosna y las multas impuestas a los cofrades.

En Cocentaina, junto con los demás cofrades, podían hacer nuevas ordenanzas. En Alcoy y Biar si había estatutos o palabras dudosas podían exponerlos a peritos en leyes para su correcta interpretación.

Los consejeros tienen como misión aconsejar a los mayorales en el gobierno de la vofradía, y su número es variable, desde los dos en Denia a los diez en Biar o Alcoy. 
El andador o mensajero era un empleado de la cofradía y sólo aparece en Denia con la misión de llamar a los cofrades a capítulo y recoger el dinero que pagaban. Cobraba 20 sueldos anuales y 3 sueldos por cada nuevo ingreso.

\section{LAS ÓRDENES RELIGIOSAS}

La presencia de las órdenes religiosas en tierras alicantinas podemos calificarla de tardía y escasa, sobre todo si la comparamos con la zona central del reino. El poblamiento cristiano fue escaso y tardío, y la red urbana era débil en los primeros años de dominio cristiano. Con todo, a fines de la Edad Media, coincidiendo con el desarrollo económico y urbano de la zona, se producirá una eclosión de conventos por todo el territorio, en particular de los franciscanos, a la par de las nuevas formas de espiritualidad individual o colectiva, como las ya vistas cofradías o el movimiento eremítico. $Y$ frente a los éxitos también se produjeron fracasos, intentos fallidos, como los jerónimos de Jávea o los agustinos en Orba, consecuencia de la inseguridad del campo en una zona de frontera como Alicante o de unas bases económicas deficientes.

\section{LOS MERCEDARIOS.}

En 1218 y por iniciativa de San Pedro Nolasco, San Raimundo de Peñafort y con el apoyo de Jaime I se funda la Orden de la Merced, encargada de la redención de cautivos cristianos en territorio musulmán. Fue reconocida por Gregorio IX en 1235, que le impuso la regla de San Agustín y el hábito blanco, mientras que Jaime I propuso como hábito mercedario el escudo real del reino y una cruz blanca sobre él.

R.I. Burns califica a estas instituciones que, movidas por la caridad, surgieron para rescatar cautivos como "órdenes rescatadoras" (55), como las de Calatrava y Trinitarios. Su difusión por el reino de Valencia vino propiciada por la propia dinámica de la reconquista e incluso antes, pues se dice que San Pedro Nolasco estuvo en la Valencia musulmana rescatando cautivos en cinco viajes. Lo cierto es que a finales del siglo XIII había en Valencia siete casas (Valencia, Puig, Xàtiva, Arguines, Denia, Burriana y Segorbe), que se constituyeron en una entidad propia. La orden combinaba "Ios ideales de cruzada, obras corporales de misericordia y oración" (56). 
Sin embargo, no todas las casas tuvieron la misma fortuna en su posterior devenir histórico. Así, sabemos que en 1245 el rey regaló a los mercedarios ocho jovadas de tierra, cuatro hanegadas y un hospicio para mantener un hospital al servicio de los cautivos pobres. Parece que también en este periodo de la segunda mitad del siglo XIII tenían un fuerte en Ondara (57). Lo cierto es que la casa de Denia debió entrar en una etapa de decadencia pues no se menciona en el capítulo general de 1317.

Aunque no aparece mencionado en la lista de conventos arriba citada debemos referirnos al convento de la Orden de la Merced de Cocentaina, cuya fundación y posterior desarrollo, entre la tradición y la realidad históri$\mathrm{ca}$, se hace remontar a 1248 por el propio rey Conquistador. Según el Padre Agustín Arqués, en sus manuscritos "Memorias de Cocentaina" el convento se fundó fuera de la villa, entre Cocentaina y Alcoy, en el paraje que luego se dênominó la Torreta de Fitor, al pie del Monte del Castell. Para ello se apoya en diversos documentos, como la donación hecha por Jimẹ́n de Castalla, vecino de Cocentaina, de ciertas tierras a Fr. Domingo de la Paz, comendador del convento mercedario de Cocentaina. También aduce una bula de Urbano IV en la que pone bajo su protección todas las casas de la Merced fundadas hasta la fecha, más las fundadas hasta 1262, figurando entre las añadidas la de Cocentaina. Por último, tres bulas pontificias de Clemente IV, 1267; otra de Gregorio X de 1272, y una tercera de Nicolás IV en 1292, en todas las cuales se menciona en convento de Cocentaina (58).

La primera noticia en la documentación local sobre esta orden es de 1305, año en que los hermanos Vicent y Ramón Capcir tienen en conjunto un censo de los frailes de la Merced, que desean dividirse entre ellos (59).

No fue muy duradera la presencia mercedaria en Cocentaina y a mediados del siglo XIV se produjo la ruina del convento como consecuencia de la guerra de la Unión, que asoló al reino de Valencia. Para el P. Pedro de San Cecilio su desaparición tuvo lugar durante la guerra de los dos Pedros, pocos años más tarde. Sin embargo, mayor crédito merece la opinión del P. Arques, también mercedario y analista de la Orden, que opina que el convento de Cocentaina fue de los primeros en arruinarse en el reino como consecuencia de la adhesión de sus frailes al bando de Pedro el Ceremonioso, frente a los unionistas, a los que se había adherido la villa de Cocentaina, mientras que su señor Alfonso Roger de Lauria era fiel al rey.

Según Arques, la destrucción se produjo cuando Jiménez de Urrea, jefe de los unionistas, tenía sitiada la villa en 1348, al mantenerse los merce- 
darios fieles al rey y entorpecer el convento, por razones estratégicas, el cerco de la villa, recuperada por sorpresa por Roger de Lauria (60). Sea cual fuere la realidad de los hechos, to cierto es que tanto la guerra de la Unión como la de los dos Pedros, poco después, supusieron un durísimo golpe para estos pequeños conventos, muchos de los cuales ya no pudieron recuperarse por razones demográficas, económicas, etc. Recordemos que ello coincide con el periodo de máxima inflexión en la llamada "crisis del sigio XIV". Lo cierto es que el posterior intento de reedificar el convento, aún cuando contaba con el beneplácito y el apoyo de Pedro el Ceremonioso, no llegó a plasmarse en una realidad. Del número de frailes, propiedades, etc. de este convento contestano nada sabemos por el momento.

En Orihuela fue donde los mercedarios consiguieron un mayor arraigo, tanto social como temporal, en estos siglos medievales. También en el caso oriolano se desconoce la fecha exacta de fundación del convento, que se hace remontar a 1256, atribuyéndoselo -una vez más- al propio Jaime I, mientras que para otros autores fue en 1243, 1249, 1265, etc. Lo cierto es que en la documentación coetánea no hay noticias sobre este convento, por lo que Vilar piensa que su instalación debió producirse tras la incorporación de la villa a la Corona de Aragón con Jaime II (61), localizándose su primitivo emplazamiento en las afueras de la villa, en el Ravalet, junto a la acequia de Almoradí, donde después se asentaron las monjas franciscanas de San Juan. Parece que primero llegaron dos frailes con recomendación real y recibieron del Consell un solar en el Ravalet y dinero para comenzar la construcción del edificio.

La guerra con Castilla a mediados del Trescientos ocasionó la ruina del convento, al ser utilizado por los castellanos como baluarte frente a las murallas de Orihuela. En 1377 los frailes solicitaron una indemnización al Consell, que les fue denegada.

Cronistas e historiadores de Orihuela han venido repitiendo tradicionalmente, desde Bellot a Vilar, que la ruinosa situación del convento y el riesgo de correrías de los granadinos en busca de cautivos hizo que Pere Roca, valedor de los frailes y miembro de una notable familia de la oligarquía local, los trasladara al interior de la ciudad, y el 15 de febrero de 1377 les cedió unas casas que tenía junto a la muralla, cerca de la puerta de Elche (62). Pronto surgieron diferencias con el Consell porque se habían instalado sin permiso y no respetaron los límites de la propiedad cedida, tapiando un callejón de muralla que llevaba a la torre de Navaflor. Roca defendió a los frailes y garantizó que derruiría la tapía y el convento si era perjudicial para la defensa de la villa en caso de guerra. 
La realidad de los documentos es diferente y sabemos que en junio de 1371 el nuevo convento de mercedarios ya funcionaba intramuros de Orihuela. En efecto, el comendador y los frailes habían comprado un albergue semiderruido y unos patios donde edificaron un monasterio, en el que, con permiso del obispo de Cartagena, construyeron una iglesia (comendator et fratres eiusdem Ordinis et conventus intus menia dicte ville quedam de eorum peccunia emerint hospicia et patis, in quibus eorum de novo hedificarunt monasterio, in quo de voluntate episcopi Cartagenie ecclesiam construxerunt...).

La popularidad de los mercedarios siempre fue alta en Orihuela, lo que les atrajo los celos y la envidia del clero secular local, quienes ese año se dedicaron a difamarlos, atribuyéndoles extraños crímenes, lo que obligó a intervenir al obispo murciano, que, haciéndose eco de las calumnias los llevó presos a Cartagena, donde los tuvo encadenados en la cárcel. El maestre de la Orden notificó la afrenta a Pedro IV, que, como protector de la Orden, mostró su asombro al prelado por tales afrentas, solicitando la puesta en libertad de los frailes (63).

Más tarde, el 20 de noviembre de 1376, el Consell quiso obligarles a contribuir en los gastos de la ciudad por el nuevo convento, pero el rey se lo impidió. Por tanto, como se ve, la nota característica de los mercedarios en Orihuela sería la tensión, con el clero local porque se ganaba el fervor y el favor de los fieles, con sus dádivas y legados piadosos, en detrimento de las parroquias de la villa; con el Consell por su altanería, sus abusos e irregularidades constructivas y sus exenciones fiscales. $Y$ ello se mantuvo en el resto del periodo medieval. Ya en 1387, el comendador de Orihuela, Francesc Plà, tuvo que enfrentarse a las ofensas que se infringían a los frailes por los curas locales, a causa de las misas y de otros oficios religiosos (64).

En el siglo XV hay que registrar la oposición del Consell a que hubiera forasteros al frente del convento, o la oposición en 1470 del cabildo colegial a que los mercedarios impartieran bendiciones post partum o recibieran ofrendas de las recién paridas, testimonio de que el establecimiento religioso se había convertido en un centro de devoción popular.

El convento mercedario fue fiel colaborador de la monarquía, que era la que garantizaba sus privilegios, su protectora, y en 1390 ayudó a Juan I con 15 carros de trigo y de cebada, y en 1396 con otros 29 carros de grano a Martín el Humano para la guerra contra el conde de Foix (65). 
Hecho notable en sus anales fue el albergar en 1410 los muros del convento al notable prdedicador fray Vicente Ferrer, que visitó la villa ese año, acompañado del mercedario fray Gilabert Jofré.

El otro convento de la Orden que también llegó hasta los tiempos modernos fue el de Santa Lucía de Elche. Fundado en 1270 por el infante don Manuel, que dió a los mercedarios los baños viejos situados en la puerta de la Calahorra, junto con el cementerio de los moros, adyacente al baño, en el camino de Alicante, construyeron una capilla con el fin de realizar la misa diaria (66).

No conocemos bien sus vicisitudes históricas y tan sólo nos han llegado algunas noticias dispersas, que hacen suponer que debió sufrir las consecuencias de la guerra de Castilla, lo que traería una cierta desorganización, pues vemos que a principios del siglo XV, en 1401, el comendador del convento, Bertomeu Desprats, reclamaba un censal de 20 sueldos anuales, legado por Jaume de Sant Martí, que gravaba un trozo de tierra, viñedo y frutales en el término de Elche, pero que hacía más de 40 años que no se cobraba, lo que ahora se tratará de hacer del detentor de la tierra.

En este plan de reorganización habría que situar la queja de este comendador contra los notarios de Alicante, Orihuela y Elche porque no les muestran las escrituras ni le dan copias de los legados testamentarios hechos para redimir cautivos, ya que según parece los albaceas y herederos no eran muy propicios a respetarlos, por lo que hubo de intervenir el rey a favor de obligar a los notarios a entregar dichas escrituras (67).

Otra amenaza siempre pendiente sobre los frailes en tierras de la gobernación oriolana, y por tanto valencianas, fue la intervención del obispo de Murcia, a cuya diócesis pertenecían. En 1404 fray Pere Guillem regía la casa mercedaria de Elche y se quejaba al rey porque el obispo de Murcia, Pablo de Santa María, quería ejercer jurisdicción sobre la comanda ilicitana. El 28 de septiembre el rey Martín el Humano le recordaba al prelado que dicha jurisdicción correspondía a los reyes aragoneses como fundadores de la Orden, y amenazaba con confiscarle las rentas en sus tierras si intervenía contra los mercedarios de Elche (69).

\section{LOS DOMINICOS}

En tierras alicantinas la única fundación de la Orden de los Predicadores fue en Orihuela y en fecha tardía, en el siglo XV. Los orígenes del 
asentamiento dominico en esta ciudad están sumidos en la penumbra y fueron objeto de encendidas polémicas en el siglo XVIII entre los frailes de la Orden fray Luis Galiana y fray José Teixidor sobre la existencia de un primer convento dominico en la ermita de San Ginés de la Jara desde principios del siglo XV, teoría defendida por el primero de los frailes y considerada por Teixidor como pura fantasía.

Algunos eruditos locales del pasado (Esplugues, Montesinos) atribuyeron la fundación del convento a varios dominicos procedentes de Valencia: fray Leonardo Gabald, fray Prudencia Belmonete, fray Juan Waldesco y fray Pedro Pérez, que en 1409 se establecieron en San Ginés de la Jara hasta 1413, fecha en que se trasladaron a la finca Lo Matet, en una heredad del noble Enrique Masquefa, huyendo del peligro de las correrías granadinas. Por su parte, el cronista Bellot dice que en 1497 había en la ermita de San Ginés frailes dominicos, a los que el Consell mandó abandonar dicho lugar (70).

La primera mención concreta del convento dominico es del 22 de agosto de 1462 en el testamento de Leonor Masquefa, que dejaba a la reducida comunidad de Lo Matet, establecida bajo la advocación de San Pedro, un legado para que se dijeran treinta misas anuales a perpetuidad por su alma. Es un testimonio no directo, sino de un catálogo posterior y, según Vilar el primer testimonio seguro sobre los dominicos sería de 1497.

Lo cierto es que de momento no han aparecido en los archivos datos que permitan precisar más sobre los dominicos en Orihuela. Parece probable -y así lo aceptan Gisbert y Vilar- pensar en un inicial asentamiento perirubano, extramuros de la ciudad, en una propiedad señorial, de los Masquefa, y el hecho de que sea una dama miembro de este linaje la que les hace un donativo hace pensar en la extrecha conexión de los dominicos con la familia, en una especie de posible capellanía señorial, de reducidos miembros, que compaginan esta orientación privada con las actividades públicas en la ciudadanía, de acuerdo con el espíritu de la Orden. Pero de momento nada sabemos sobre esta posible proyección pública de los dominicos en Orihuela, que luego sería tan importante.

De hecho, hasta principios del siglo XVI los dominicos no se instalaron en Orihuela, coincidiendo con un suceso milagroso en medio de la epidemia de peste que azotaba la ciudad en 1510, cuando la Virgen se apareció al jurado Andreu Soler y le comunicó que el mal cesaría si los dominicos se instalaban en la urbe. La historia es poco verosimil y tiene todo el aire de haber estado preparada por los mismos frailes para conseguir su insta- 
lación en la ciudad, aprovechando un momento de tensión en los espíritus como sucede siempre en una epidemia, donde cualquier fórmula era buena para aplacar la ira divina, causante del mal. Instalar a los dominicos, que propagarian el rosarío y purificarían los espíritus, era un buen remedio. El Consell les asignó la ermita de la Virgen del Socorro y San José, y la nueva instalación fue aprobada por el papa Julio II en 1512, recibiendo a partir de entonces privilegios de Fernando el Católico y Carlos I. Este puede ser considerado el auténtico punto de partida de la presencia y el despegue de su influencia en la ciudad de Orihuela, tardío, como se ve, y en un momento difícil -el siglo XV-, en que tenía como competidores a mercedarios, agustinos o franciscanos, más arraigados en el pueblo.

\section{LOS AGUSTINOS}

Al igual que los jerónimos, también los agustinos tenían un origen eremítico, siendo reconocidos por Alejandro IV en 1256, pero pronto dejaron la vida contemplativa por la predicación, la enseñanza y el cuidado de las almas como mendicantes. Pronto se difunden por toda Europa y en el reino de Valencia, coincidiendo con la repoblación del mismo por los nuevos pobladores cristianos.

Hacia 1280-1290 el territorio valenciano contaba con cinco conventos de agustinos: el de Aigües-Vives, que fue el primero, el de Castellón, Alzira, Valencia y Alcoy, que por estas fechas está situado en plena frontera con Castilla y en territorio de población mayoritariamente cristiana.

El destruido monasterio de San Agustín de Alcoy se levantaba extramuros, en la manzana comprendida entre la plaza de España, edificio del Ayuntamiento, Instituto Nacional de Previsión, Caja de Ahorros Provincial, San Lorenzo, Valls y Escola. Sobre sus orígenes el problema, aquí como en otras fundaciones, es poder precisar o aproximarse a la fecha en que se erigió. El alcoyano Jaume Jordán en su obra "Historia de la Provincia de la Corona de Aragón" (Valladolid, 1704), atribuye la construcción del convento a Saurina de Entença, esposa del almirante Roger de Lauria, en 1290, noticia que fue aceptada por cronistas e historiadores posteriores (71).

También una vez más entre esta fecha que se daba como cierta y la primera vez que aparece documentado el monasterio había una gran laguna temporal hasta los años cuarenta del siglo XIV. Ya el padre Picher en su obra manuscrita sobre la historia de Alcoy, fechaba con toda precisión 
la fundación del monasterio el 26 de julio de 1338, debido a Margarida de Lauria y Entença, hija de Saurina de Entença y de Roger de Lauria, y mujer del conde de Terranova. Las investigaciones de R. Bañó en torno a los testamentos alcoyanos muestran que la primera mención del monasterio agustiniano es de 29 de diciembre de 1340 y el testamento de Margarida es claro cuando especifica que fue ella quien hizo construir el monasterio.En él residirían unos 20 frailes, percibiendo anualmente un censo de 4.000 sueldos de las rentas de la villa de Alcoy. Na Margarida lo dotó con diversas propiedades: las del Olivar, Botjar, Olm, Lloba y senda de les Ombries. El 1 de noviembre de 1382 el rey autorizaba al convento para que, a pesar de las prohibiciones expresas de los Furs, que no permiten a los eclesiásticos tener bienes de realengo, pueda percibir las rentas de una capellanía fundada por el conde de Terranova (74).

Para su construcción se aprovechó un antiguo castillo, construido por los alcoyanos con ocasión de las guerras de Murcia en 1265. Su arquitecto fue Berenguer Jofre y trabajaron diversos canteros de Valencia, Murcia, Xàtiva y Montesa. Las capillas se construyeron en 1346. En los gastos de la obra contribuyeron los moros de Seta y Travadell. El primer prior fue Guillem Desprats.

El edificio estaba dotado de dos puertas, una la de la iglesia y otra la del convento. Ignoramos cuándo se construyó la portada gótica que se aprecia en las fotografías hechas antes del derribo. Convento e iglesia estaban rodeados de un foso, que los convertía en una auténtica fortaleza, y esta función es la que cumplió en la guerra de los dos Pedros entre Castilla y Aragón a mediados del siglo XIV.

Las relaciones entre los agustinos y las autoridades locales de Alcoy fueron más tensas de lo que hubiera sido de desear, en particular por el pago anual de la mencionada cantidad, que a los jurados siempre se les hacía cuesta arriba, o por las cuestiones derivadas del aprovechamiento del agua de la Font del Molinar, a cuya traida de aguas contribuyeron los frailes de San Agustín, pero en 1423 el prior del convento, Antoni Biosca, denunció al Consell porque no entregaba al convento el agua que le pertenecía, pleito que se prolongó en años sucesivos.

En el primer tercio del siglo XV hubo un intento de fundar un convento de agustinos en tierras del norte de Alicante, pero resultó fallido. Guerau de Castell Vera, que fue señor del valle de Orba y falleció en 1422, dispuso que con sus bienes los frailes de San Agustín pudiesen fundar un convento en dicho valle, dándoles las rentas suficientes -3.000 sueldos- para 
que pudiesen subsistir. Tal medida no fue bien vista por los herederos, que pleitearon para anular tal donación, per ésta fue ratificada por el monarca. El pleito lo mantuvieron fray Jaume Tarragó, maestro en Sagrada Teología y procurador del provincial agustino de Aragón, y Bernat Sanç, alias Ripoll, caballero y administrador de Guerau Sanç y sus hijos. El 14 de diciembre de 1428 Alfonso $V$ escribe al gobernador del reino ordenándole que respete su decisión de dar como válida la donación a los frailes (75).

El otro convento agustino en tierras alicantinas se encontraba en Orihuela, cuyas fechas de erección no estaban precisadas, oscilando entre 1390 y 145 (76). Ahora podemos precisar que no fue anterior en ningún caso anterior a 1394. El 4 de febrero de ese año Juan I ordena a las autoridades de Orihuela y a los sacerdotes de la villa que no pongan trabas a los frailes agustinos que quieren edificar un monasterio, para lo cual cuentan con la licencia papal. El motivo era las quejas de los frailes por las trabas que se les ponían (77). Recordemos que por aquellas fechas los mercedarios habían reanudado sus actividades en la villa tras los desastres de la guerra de Castilla y tanto ellos como el clero regular no verían con buenos ojos la competencia espiritual y económica que podía suponer la instalación de una nueva Orden.

Si los Roca fueron valedores de la Orden de la Merced, Ramón de Rocafull y Jaume Masquefa, miembros de dos de las familias más destacadas de la oligarquía local serán los protectores del nuevo convento, cuyos comienzos fueron más bien modestos, ya que en 1400 el convento, de frágiles muros, amenazaba ruina y era un peligro para sus moradores.

El Consell dió algunas sumas de dinero y se hizo una cuestación en la villa, pero las obras fueron muy largas hasta ultimarse en 1499, tras una nueva etapa de reedificación iniciada en 1463.

Conviene destacar que los agustinos gozaron de gran prestigio en la ciudad, entre las autoridades y los particulares. El Consell consultaba al prior en cuestiones relevantes, como fue la sucesión al trono al quedar vacante tras la muerte de Martín el Humano, el pleito del obispado y otros muchos asuntos. En los actos solemnes a los que se invitaba a las corporaciones religiosas los agustinos ocupaban el primer puesto, lugar que más tarde les disputarían los dominicos, dando lugar a violentas polémicas que escandalizaron a los vecinos y forzando a la intervención de los jura$\operatorname{dos}(78)$. 


\section{LOS FRANCISCANOS}

La presencia de los frailes menores en el reino de Murcía -al que pertenecían las tierras meridionales alicantinas durante el siglo XIII- databa de tiempos de la conquista, con un convento en la propia Murcia. Sabemos que en este siglo XIII hubo intentos de fundar otros conventos en la localidad de Alicante, como se desprende de la orden dada el 23 de abril de 1282 por Pedro III, rey de Aragón, a los bailes y peajeros del reino de Valencia para que autorizaran el paso de madera por el río Júcar, ya que el infante castellano don Sancho sacaba 4.000 troncos con destino a la construcción de los conventos de Murcia y Alicante (79). No hay noticias posteriores que permitan suponer que el convento de Alicante se construyera.

Habrá que esperar a mediados del siglo XV para que tanto Orihuela como Alicante vean erigirse sus respectivas fundaciones de franciscanos. No se trata de un hecho aislado, sino que responde a una tendencia general de la época, visible muy bien en el reino de Murcia donde el número de conventos de frailes menores aumenta a siete. Es una consecuencia de los movimientos reformadores que se dejan sentir en el seno de la Orden, dividida entre conventuales y observantes, siendo estos últimos, rigurosos seguidores de la regla de San Francisco, los que se establecen en las localidades alicantinas.

Se produjo también por entonces una tendencia revitalizadora de la espiritualidad ciudadana por toda la península, nuevas orientaciones religiosas que alcanzan rápido éxito en los centros urbanos, como es el caso de los franciscanos en Alicante y Orihuela, localidades en una etapa de crecimiento, lo que las hace marco propicio para la captación de almas. Es muy interesante señalar cómo en ambas localidades la fecha y el punto de partida son similares: 1440 y una ermita. En Alicante con las bulas de Gregorio VII y Urbano II autorizando a los reyes de Aragón a erigir todo tipo de iglesias, monasterios y sedes en sus reinos, salvo obispados. Aquí jugó un destacado papel la política internacional de Alfonso el Magnánimo en sus relaciones con la Santa Sede, con sus continuos vaivenes, su tira y afloja en torno a la cuestión del pretendido obispado de Orihuela y al control eclesiástico de las tierras sureñas del reino de Valencia, que en lo religioso dependían de la diócesis de Cartagena. Ampliar la red de establecimientos eclesiásticos en esta zona con clérigos o frailes fieles a la Corona aragonesa era una medida hábil frente a futuras aspiraciones religiosas.

En Alicante, el soporte material del futuro convento de franciscanos sería la ermita de los Angeles, situada en el plà del Bon Repos, a un kiló- 
metro al NO de la ciudad, en la carretera de San Vicente. Los origenes de la ermita, como ya dijimos, se vinculaban a un suceso milagroso, que la tradición relacionaba con el hallazgo de una imagen de la Virgen encontrada entre las malezas por un leñador, tras haber sido ocultada para evitar las profanaciones de los musulmanes. Lo trascendental es que esta Virgen se convirtió con el tiempo en la patrona de Alicante, en un foco de devoción popular.

El cronista local Viravens (1876) señala que el convento tenía unos veinte metros de largo por siete de ancho, estando la puerta principal al oeste; en él había siete altares y en el mayor, el más amplio, se veneraba la Virgen de los Angeles. Cuatro arcos de piedra sostenían una sencilla cúpula, que iluminaba el sencillo edificio. Al sur se hallaba el sencillo claustro con una cisterna. Las celdas para los nueve religiosos que se establecieron estaban en un piso alto, y el conjunto disponía de un huerto cultivado por los frailes (80). Ignoramos a qué época se refieren las construcciones citadas, pero por el dato de la cúpula habría que situarlas en los tiempos modernos.

La comunidad debía ser reducida al principio, nueve miembros o quizá menos, y nada sabemos de sus actividades, aunque es posible que practicaran la vida ermitaña, al menos en un principio, como hacian otros muchos conventos franciscanos por toda la península. Sería interesante conocer -aunque con las fuentes actuales es imposible-cuál fue la vinculación de los franciscanos con la ciudad, como receptores de unas formas específicas de religiosidad, a través de la predicación; sus relaciones con las autoridades y los estamentos sociales, su grado de aceptación, etc. Pero el convento franciscano de Alicante en sus primeros tiempos sigue siendo un reto para futuras investigaciones.

En el caso de Orihuela no nos ha llegado documentación de la época en que los franciscanos se instalaron en la ciudad y todas las noticias proceden de los ya habituales cronistas Bellot y Giisbert, luego recopiladas por Vilar, al que seguimos en sus líneas generales. Conviene señalar que, al igual que en Alicante, los siglos XIII y XIV fueron una etapa de inmovilismo fundacional de conventos franciscanos, hasta que en 1440 algunos vecinos de Orihuela intentan que se eriga en la ciudad un convento, pero el proyecto fracasó, sin que sepamos las razones.

Hay un factor importante a señalar y es que la instalación de los mendicantes aquí fue iniciativa de los grupos dirigentes urbanos, bien a iniciativa personal, bien canalizados a través del Consell, que en 1449 entrega a 
la Orden Franciscana la ermita de Santa Ana para que se instalen en ella. Ocho años más tarde los jurados intentaron convertir la ermita, pero fracasaron, quizá por la oposición de la familia Rocafull, dueña del terreno, o por las disenciones en la orden franciscana. Hubo intentos y gestiones por parte de las autoridades locales en 1453 ante el provincial de los franciscanos en Aragón para que levantaran un convento, ofreciendo terrenos y ayuda, pero tampoco se llegaron a buen puerto, debido a las tensiones entre conventuales y observantes. El patriciado oriolano era partidario de los observantes y en 1456 parece que el convento ya estaba en marcha, términándose hacia 1464. El de Orihuela fue autorizado por Nicolás $V$ y en 1480 se constituyeron en custodia observante de Murcia (81).

Como complemento a los franciscanos observantes se instalaron en Orihuela a fines del siglo XV las clarisas observantes, con unos precedentes difusos, que se remontan a 1474 y cuyo objetivo era atender las vocaciones femeninas de la comarca y evitar su salida hacia otros lugares. La iniciativa había partido también del Consell, pero los resultados se demoraron unos años hasta su fundación definitiva en 1493, aunque la bula de autorización para erigir el convento la dió Inocencio VIII el 17 de febrero de 1490, con la condición de que perteneciera a la obediencia de los observantes de la provincia de Cartagena.

El 10 de agosto de 1493 llegaron siete religiosas del convento de Santa Clara de Murcia que materializaron la fundación, siendo la primera abadesa Sor Inés Marín. Como edificio utilizaron un antiguo monasterio situado en las afueras, extramuros, construido en 1321 y que quedó abandonado tras la guerra de los dos Pedros. En 1499 recibió el nombre de monasterio de San Juan Bautista de la Penitencia.

En el origen de este convento encontramos las donaciones de una viuda local, que en su testamento encarga a su hija que cediera parte de su hacienda para crear un monasterio de Santa Clara. Los eruditos no se pusieron de acuerdo sobre este personaje, que según Montesinos sería una señora llamada Crespa, viuda del ciudadano Joan Ontinyent, observante de los preceptos de la orden tercera de San Francisco. Según Bellot, fue la viuda de Andreu Ontinyent la que erigió el monasterio, mientras que para Morales fueron dos señores Cascant, o la viuda de Marc Rosell, según Madoz.

Lo importante, sin embargo, eran los estrechos lazos, las conexiones que se habían establecido en Alicante y Orihuela entre ambas ciudades y el franciscanismo a fines de la Edad Media. Ello no era nada nuevo ni ori- 
ginal en relación a lo que venía sucediendo en el resto de Europa desde hacía tiempo. Solo que aquí llegaba con más retraso, fruto de la peculiar evolución de ambas localidades, que se recuperan e inician su despegue hacia el mundo moderno en la segunda mitad del Cuatrocientos, sobre todo Alicante. En Valencia, en cambio, la tradición era mucho más antigua. Diversos autores han destacado los estrechos lazos entre franciscanismo y espíritu burgués precapitalista, como hizo Maravall (82), por lo que no insisto en el tema.

El franciscanismo es el resultado de la cultura urbana y en las ciudades erigen sus conventos, contando con el apoyo de mercaderes y demás burgueses enriquecidos con las actividades comerciales. El mensaje franciscano de pobreza y humildad respondía a la demanda ideológica de determinados grupos sociales urbanos, sobre todo los más elevados. De ahí el apoyo que encuentran en el patriciado de Alicante y Orihuela, en donde la fundación de estos conventos ratifica el carácter más urbano que van adquiriendo estas localidades, sancionado con la concesión del título de ciudad a ambas villas por estas fechas. Hay, por tanto, una clara correlación entre la difusión de ambas órdenes y la configuración de la ciudad como tal, siendo una pieza más del sistema urbano.

\section{LOS JERÓNIMOS}

Los religiosos jerónimos aparecen en el siglo XIV en distintos reinos peninsulares. En principio eran ermitaños que, en pequeños grupos, vivían practicando la austeridad y la penitencia, pretendiendo resucitar las formas de vida acordes con la exigencia evangélica de pobreza.

En el reino de Valencia aparecen grupos de estos ermitaños en Alzira y Denia a mediados del siglo XIV. Las noticias nos han llegado recopiladas por Roque Chabás en su "Historia de Denia", donde nos narra el asentamiento de tres o cuatro de estos ermitaños en la meseta del cabo de San Antonio. Su número fue en aumento, hasta llegar a la docena, estando dirigidos por el sacerdote valenciano fray Joan Ivanyes.

Estos anacoretas trabajaban la tierra para proporcionarse el sustento necesario, dedicando el resto del tiempo a la vida contemplativa. Imitándolos surgió otro grupo de ermitaños en el valle de Miralles, en el término de Alzira. En 1350 se agregaron a estos grupos otros ermitaños procedentes de Italia, según Chabás, aunque nunca indica la fuente de todas estas no- 
ticias. Quizás huyeron de las epidemias que sacudían estos países. La dislocación social, los movimientos de población y la exacerbación de las actitudes religiosas, como la de estos hombres que practicaban la penitencia extrema, son propias de momentos de crisis y dificultades.

Siendo ya bastante numerosos decidieron reunirse y vivir bajo una misma regla, vistiendo el mismo hábito y eligiendo un superior, según el ideal monástico de San Jerónimo, para lo cual enviaron una petición de autorización al papa Gregorio XI, residente en Aviñón, que el 18 de octubre de 1373 había concedido la bula solicitada a los de Castilla, y poco después, el 13 de agosto de 1374 les concedió la misma bula y permiso para levantar tres monasterios. Los comisionados ante el papa fueron Francesc Massanet, Jaume d'Olentori y Jaume Joan Ivanyes.

De este modo se funda en el reino de Valencia el primer monasterio jerónimo en el cabo de San Antonio. Su vida fue efímera, ignorándose el nombre que tuvo. Desde el primer momento contó con el apoyo de don Alfonso, conde de Denia, igual que sucedió con los otros ermitaños instalados en la comarca. Les designó un lugar para edificar el monasterio, allí donde se levantó la posterior ermita de Nuestra Señora de los Angeles, y les dió rentas -ignoramos cuáles- para su mantenimiento. Chabás dice que el monasterio estaba levantado al año siguiente, lo que hace pensar que sería una construcción muy sencilla, acorde con el espíritu de pobreza de los frailes. Fue el primer abad el padre Ivanyes.

El monasterio tuvo una corta vida, pues en 1386 fue saqueado por piratas de Bugía, que desmantelaron el edificio y se llevaron cautivos a ocho monjes, dando muerte al prior, pudiendo escapar otros tres religiosos, que continuaron llevando vida penitente en los alrededores.

En 1392 los religiosos cautivos fueron recatados por el duque de Gandía, don Alfonso, que les dió un lugar cercano a Gandía, llamado Cotalba, donde erigieron el monasterio de San Jerónimo, quedando abandonado el de Denia, aunque la vida eremítica, como vimos en otro apartado, siguió practicándose en la comarca (83). 


\section{NOTAS}

(1) DEL ESTAL, J.M. Conquista y anexión de Alicante, Orihuela, Elche y Guardamar al reino de Valencia por Jaime II (1296-1308), Alicante, 1982. Corpus documental del reino de Murcia bajo la soberania de Aragón (1296-1304/5). Colección de documentos medievales alicantinos I/1, Alicante, Instituto Juan Gil Albert, 1985; El reino de Murcia bajo Aragón (1296-1305). Corpus documental 1/2. Alicante, 1990. HISTORIA DE LA PROVINCIA DE ALICANTE, T. III dirigido por J. Hinojosa Montalvo, Murcia, Ediciones Mediterráneo, 1985, pp. 171285.

(2) VIDAL TUR, G. Un obispado español. Orihuela-Alicante, Alicante, 1962.

(3) BURNS, R.I. El reino de Valencia en el siglo XIII (Iglesia y sociedad), Valencia, Del Cenia al Segura, 1982.

(4) MARTíNEZ MORELLA, R. Capítulos de la cofradía de San Nicolás otorgados por Martín el Humano en 1402, Alicante, Ayuntamiento, 1964. GALLENT MARCO, M. "Las motivaciones asistenciales en dos cofradías laicas del siglo XV (Biar y Alcoy)", Anales de la Universidad de Alicante. Historia Medieval, 2, 1983, pp. 139-162. SÁNCHEZ HERRERO, J. Las cofradías alicantinas y valencianas y su evolución durante los siglos XIII al XVI, 1490: En el umbral de la modernidad. Las ciudades del Mediterráneo occidental en el tránsito de la Edad Media a la Moderna, Alicante, 1990.En prensa.

(5) FULLANA MIRA, L. Historia de la villa y condado de Cocentaina, Valencia, 1920. DIAGO, F. Anales del Reyno de Valencia, Valencia, 1613.

(6) ESCOLANO, G y PERALES, J.b. Décadas de la Historia de la insigne y coronada ciudaqd de Valencia, Madrid, 1879 y Valencia, 1880. pp. 593. FULLANA MIRA, L. op. cit. p. 270.

(7) FULLANA MIRA, L. op. cit. p. 270. Fullana se extiende en un estudio más detallado de estas profecías, en particular la recuperación de Jerusalén.

(8) DIETARI DEL CAPELLA D'ANFOS EL MAGANANIM, Introducció, notes i transcipció per J. Sanchis Sivera, Valencia, 1923. p. 184

(9) GISBERT Y BALLESTEROS, E. Historia de Orihuela, Orihuela, 1901-1903. II, p. 622.

(10) CHABÁS, R. op. cit. pp. 272-273.(11) CHABAS, R. Historia de Denia. p.p. 271-273.

(12) A.R.V. Bailia, 1146. fol. 439 r-v.

(13) A.R.V. Real, 611, fol. $170 \mathrm{v}$.

(14) CHABÁS, R. Historia de Denia. p. 273 
(15) A.R.V. Bailia, 1151. fol. $284 \mathrm{r}$.

(16) DÍAZ BORRÁS, A. Problemas marítimos de Valencia a fines de la Edad Media: el corso, la piratería y el cautiverio en su incidencia sobre la dinamíca económica: 1400-1480. Tesis doctoral, Valencia, Facultad de Geografía e Historia, 1987. Inédita; "L'estudi de la piratería a traves dels avisaments costaners. Replegament cristià y setge islàmic a la València de la transició a la Modernitat: 1480-1520, Anuario de Estudios Medievales,20, 1990. pp. 275-295.; HINOJOSA MONTALVO, J. "La piratería y el corso en las costas alicantinas durante la Baja Edad Media", VIII Jornades d'Estudis Històrics Locals. El comerç alternatiu. Corsarisme i contraban (ss. XV-XVIII). Palma de Mallorca, 1990 . pp. 41-54.

(17) A.R.V. Real, 87. fol. 168 r.

(18) CUENCA ADAM, A. "Un registro de los duques de Gandía (1402-1406). Regesta e índices", Estudis castellonencs, 2, Castelló, 1984-85, pp. 493-589. En concreto p. 544. doc. n. 315.

(19) CUENCA ADAM, A. Un registro. p. 353. doc. n. 254 y p. 556. doc. n. 401

(20) CAMPÓN, J y PASTOR, J. Historia de Calp, Calp, 1989. p. 121.

(21) RAMOS HIDALGO, A. Evolución urbana de Alicante, Alicante 1984. p. 72

(22) ARQUES JOVER. Fr. Agustín. Nobiliario alicantino. Transcripción de L. Más y Gil, Alicante, Ayuntamiento, 1966. p. 125.

(23) VIRAVENS Y PASTOR, Crónica de la muy ilustre y siempre fiel ciudad de Alicante, Alicante, 1876. pp. 41-43, donde desarrolla con mayor extensión la citada tradición y su posterior culto.

(24) RAMOS FOLQUÉS, R. Historia de Elche, Elche, 1987. pp. 523-525.

(25) BELLOT, A. Anales de Orihuela, Edición de J. Torres Fontes, Orihuela, 1954.

(26) GISBERT Y BALLESTEROS, E. Historia de Orihuela. p. 658.

(27) GISBERT Y BALLESTEROS, E. Historia de Orihuela. p. 658.

(28) GISBERT Y BALLESTEROS, E. Historia de Orihuela. p. 327.

(29) GISBERT Y BALLESTEROS, E. Historia de Orihuela. T. II. p. 549. 622; III. p. 452 y 564.

(30) VILAR, J. Bta. Historia de Orihuela. Orihuela en los siglos XIV y XV. p. 335.

(31) GISBERT Y BALLESTEROS, E. Historia de Orihuela. T. III. p. 296 y 654. VILAR, J. Bta. Orihuela en los siglos XIV y XV. p. 349.

(32) GISBERT Y BALLESTEROS, E. Historia de Orihuela, T. II. p. 538.

(33) GISBERT Y BALLESTEROS, E. Historia de Orihuela. T.III. p. 151.

(34) MARTíNEZ MORELLA, V. Capítulos de la Cofradía de San Nicolás otorgados por Martín el Humano en 1402. Alicante, 1964.

(35) GALLENT MARCO, M. "Las motivaciones asistenciales en dos cofradías laicas del siglo XV (Biar y Alcoy)", Anales de la Universidad de Alicante. Historia Medieval, 2, 1983, pp. 139-162.

(36) CUENCA ADAM, A. "Dos cofradías medievales. San Cristobal de Gandía y Santa María de Denia". Saitabi, XXV, 1985, pp. 23-37.

(37) SÁNCHEZ HERRERO, José. "Las cofradías alicantinas y valencianas y su evolución durante los siglos XIV al XVI", en el Congreso "1490: En el umbral de la Modernidad" El Mediterráneo europeo y las ciudades de los siglos XVXVI. Alicante, 1990. En prensa por el Consell Valencià de Cultura. 
(38) DUHR, J. "La confrerie dans la vie de l'Eglise", Revue d'Histoire Eclesiastique, 1939. pp. 437-478.

(39) MARSILLA DE PASCUAL, Francisco-Reyes. "Aportación al estudio de las cofradías religiosas en la diócesis de Cartagena. Siglo XV", Mayurqa, 22. Homenatge a Alvaro Santamaría, I. pp. 383-392.

(40) CARLE, M. del C. La iglesia. p. 409.

(41) GISBERT Y BALLESTEROS, E. Historia de Orihuela, III, p. 704.

(42) VILAR, J. Bta. Orihuela en los siglos XIV y XV. p. 331.

(43) SÁNCHEZ HERRERO, J. Las cofradías alicantinas y valencianas. En prensa.

(44) GISBERT Y BALLESTEROS, J. Historia de Orihuela, II, p. 351.

(45) BELLOT, A. Anales de Orihuela siglos XIV-XV. Edición de J. Torres Fontes, Orihuela, Casino de Orihuela, 1956. II. p. 310.

(46) GISBERT Y BALLESTEROS, E. Historia de Orihuela, II. p. 134; III. p. 50 y 705.

(47) VILAR, J. Bta. Orihuela en los siglos XIV y XV. p. 331, que la remonta al siglo $X I V$, pero sin aducir pruebas de ello.

(48) TORRES FONTES, J. y MOLINA MOLINA, A.L. "El monasterio de San Ginés de la Jara", Historia de Cartagena, Murcia, 1986, VI. pp.77-92.

(49) MARTÍNEZ MORELLÁ, V. Capítulos de la cotradia de San Nicolás otorgados por Martín el Humano en 1402. Alicante, Ayuntamiento, 1964.

(50) A.R.V. Real, 307. fol. 147 r-v.

(51) A.R.V. Real, 56. fol. 114 r.

(52) A.R.V. Real, 87. fol. $150 \mathrm{v}-151 \mathrm{r}$.

(53) FULLANA MIRA, Luis. Historia de la villa y condado de Cocentaina, Valencia, 1920. pp. 221-224 y documento n. 12, donde transcribe el documento original.

(54) GALLENT MARCO, M. "Las motivaciones asistenciales en dos cofradias laicas del siglo XV (Biar y Alcoy)", Anales de la Universidad de Alicante. Historia Medieval, 2, 1983. pp. 139-162.

(55) CUENCA ADAM, A. "Un registro de los duques de Gandía”. p. 35.

(56) BURNS, R.I. El reino de Valencia en el siglo XIII (Iglesia y sociedad). Valencia, 1982, p. 554.

(57) BURNS, R.I. El reino de Valencia en el siglo XIII. p. 548-551, en las que puede verse una relación minuciosa de la actividad de la orden.

(58) GAZULLA, F. "Los mercedarios en Játiva durante el siglo XIII", en Boletín de la Sociedad Castellonense de Cultura, IV, 1923, pp' 129-143.

(59) FULLANA MIRA, L. Historia de la villa y condado de Cocentaina. p. 56-57, a quien seguimos en estas noticias sobre los mercedarios en Cocentaina.

(60) ARCHIVO MUNICIPAL DE COCENTAINA, Registro de 1305. fol. $110 \mathrm{v}$.

(61) FULLANA MIRA, L. Historia de la villa y condado de Cocentaina. p. 136-137.

(62) VILAR, J. Bta. Orihuela en los siglos XIV y XV. p. 338.

(63) BELLOT, A. Anales de Orihuela. II. pp.329-330; GISBERT Y BALLESTEROS, E. Historia de Orihuela. II. p. 349; VILAR, J.Bta. Orihuela en los siglos XIV y XV.p. 339.

(64) SAINZ DE LA MAZA LASOLI, Regina. "Los mercedarios en la Corona de Aragón durante la segunda mitad del siglo XI. Noticias y documentos", en Miscel.lanea de Textos Medievals, 4, Barcelona, 1988. p. 246. doc. n.21. A.C.A. Cancill. real. reg. 754 . fol. 175 v-176 r. 
(65) SAINZ DE LA MAZA, R. Los mercedarios en la Corona de Aragón. p.246.

(66) GISBERT Y BALLESTEROS, E. Historia de Orihuela. II. p. 350.

(67) RAMOS FOLQUES , A. Historia de Elche. Elche, 1987. p. 468.

(68) FERRER I MALLOL, María Teresa. "La redempció de captius a la Corona catalano-aragonesa (segle XIV)", en Anuario de Estudios Medievales, 15, p. 270.

(69) FERRER I MALLOL, M.T. La redempcio de captius. p. 270.

(70) GISBERT Y BALLESTEROS, E. Historia de Orihuela. III. p. 369. Lo recoge VILAR, J.Bta. Historia de Orihuela. III.

(71) Así lo hace R.I. BURNS, El reino de Valencia en el siglo XIII. p. 466.

(72) BAÑÓ ARMIÑANA, Ricard. Alcoi durant el senyoriu de Frederic d'Aragó, comtede Luna: 1409-1430. Tesis de licenciatura inédita. Facultad de Filosofía y Letras, Alicante. Dice el testamento:"quiquidem monasterium nos incepimus construere..."

(73) A.C.A. Cancill. real. reg. 1687. fol. 23 v-24 r.

(74) A.R.V. Real, 462. fol. $33 \mathrm{r}-36 \mathrm{r}$.

(75) GISBERT Y BALLESTEROS, E. Historia de Orihuela, III. p. 645 da la fecha de 1390. Vilar sugiere una fundación de finales del siglo XIV, apreciación que era correcta.

(76) A.C.A. Cancill. real. reg. 1859. fol. 27 v-28 r.

(77) VILAR, J. Bta. Historia de Orihuela. T. III. p. 340.

(78) A.C.A.Cancill. real reg. 44. fol. 227 v. TORRES FONTES, J. Colección de documentos para la historia del reino de Murcia, II. doc. LXXV. p. 70.

(79) VIRAVENS Y PASTOR, R. Crónica de la ilustre y siempre fiel ciudad de Alicante. Alicante, 1876. Reedición 1989.

(80) VILAR, J. Bta. Orihuela en los siglos XIV y XV. pp. 345-348 desarrolla con mayor amplitud las gestiones del municipio para instalar a los franciscanos y las tensiones entre las dos ramas de la Orden por conseguir el control de la nueva fundación.

(81) MARAVALL, J.A. "Franciscanismo, burguesía y mentalidad precapitalista en la obra de Eximenis", en VIII Congreso de Historia de la Corona de Aragón, Valencia, 1969, I. pp.285-305.

(82) CHABÁS, Roque. Historia de la ciudad de Denia. pp. 267-270. En sus páginas hace una crítica de las diversas opiniones de los autores que estudiaron a los jerónimos, recogiendo alguna leyenda concerniente a la fuga de uno de los frailes mientras era conducido preso por los berberiscos. 